\title{
Mulheres Brasileiras em Tempo de Competição Eleitoral: Seleção de Candidaturas e Degraus de Acesso aos Cargos Parlamentares*
}

\author{
Maria Luzia Miranda Álvares
}

\section{INTRODUÇÃO}

T este artigo, a constituição de candidaturas no sistema partidário 1 brasileiro é examinada considerando-se os aspectos formais que submetem filiados e filiadas a competir em uma eleição. É verificado se os estatutos partidários registram um processo de pré-seleção de candidaturas parlamentares, considerando o sistema eleitoral brasileiro inscrito no personal vote, e se mantêm um amplo número de vagas para preenchimento de cargos legislativos.

À composição das listas se integram também critérios informais, tanto pela demanda do partido (por um dado tipo de candidato), interessado em garantir sua representatividade ao ganhar os votos do eleitorado, quanto pela oferta de nomes de filiados/as desejosos/as de concorrer ao avaliarem, positivamente, seus antecedentes sociais e políti-

\footnotetext{
* Este texto foi apresentado no XXIX Encontro Anual da Associação Nacional de Pós-Graduação e Pesquisa em Ciências Sociais-ANPOCS, de 25 a 29 de outubro de 2005, tendo sido escolhido para publicação na Revista Brasileira de Ciências Sociais. Trata-se de uma síntese da tese de doutorado intitulada Mulheres na Competição Eleitoral: Seleção de Candidaturas e o Padrão de Carreira Política no Brasil, orientada por Jairo Nicolau e defendida em agosto de 2004 no Instituto Universitário de Pesquisas do Rio de Janeiro IUPERJ. O estudo em questão é muito mais amplo e visa avaliar os degraus de acesso das mulheres à carreira parlamentar por meio de uma função partidária - recrutamento de candidatos.
}

DADOS - Revista de Ciências Sociais, Rio de Janeiro, Vol. 51, no4, 2008, pp. 895 a 939. 
cos. Nesse caso, se não existem empecilhos legais para a entrada das mulheres na competição eleitoral e se as vagas nas listas partidárias na maioria das vezes não são preenchidas, por que as candidaturas femininas ainda se apresentam em desnível em relação às masculinas?

As seções deste artigo se detêm nas teorias sobre a formação dos tipos de ator integrado ao jogo eleitoral e à seleção de candidaturas ou sobre a indicação nominal nas listas partidárias, assuntos que têm sido estudados pela literatura como uma função essencial dos partidos políticos (Duverger, 1970; Czudnowski, 1975; Gallagher e Marsh, 1988; Hazan, 2002; Pennings e Hazan, 2001), permeando um mercado que oferta e demanda candidatos/as. Essa função é examinada, primeiramente, a partir dos modelos do gatekeeper, de Norris e Lovenduski, e do selectorate, de Reuven Hazan. Segue-se a aplicação desse último modelo na avaliação de três estatutos de partidos brasileiros, verificando-se o tipo formal do "selecionador" de candidaturas sobre os/as filiados/as partidários/as. A terceira seção evidencia o acesso das mulheres ao Legislativo, enquanto candidatas, em dois períodos (1946 a 1982; 1986 a 2002), mostrando o relativo crescimento do número de filiadas que ascende a esse status e o percentual de eleitas. Na última seção, é avaliado se o processo de seleção formal interfere nos degraus de acesso das brasileiras aos cargos legislativos em que ainda se acham sub-representadas e/ou se são outros os obstáculos que reduzem o ímpeto da representação parlamentar desse gênero.

\section{ATORES PARTIDÁRIOS E MODELOS DE SELEÇÃO DE CANDIDATURAS}

O sistema democrático representativo se legitima pelo consenso de eleições livres e do sufrágio universal, sendo os atores principais nesse sistema os partidos políticos e os cidadãos e cidadãs que participam, seja com o direito a se elegerem, seja com o direito a elegerem outrem para um determinado cargo político em um período específico. O sistema eleitoral, que dita as regras do escrutínio, e o sistema partidário, que expressa a organização dos/as cidadãos/ãs para a conquista de cargos eleitorais, constituem as instituições mais importantes para o desempenho da participação via representação política.

Os partidos políticos têm papel fundamental na organização das demandas institucionais para o ingresso do cidadão e da cidadã (como eleitor/a e como aspirante ao cargo eletivo) na vida política de um país. Duverger (1970) tratou do assunto em regimes de democracia re- 
presentativa, evidenciando os enfoques da seleção diferenciada entre os tipos de partido e da relação entre pré-escrutínio (pré-seleção) e designação de candidatos, observando a variabilidade do grau de intervenção dos partidos e a sutileza que é usada na relação entre estes e os candidatos na ratificação dos nomes - oficializada pelas organizações partidárias - e nas negociações que ocorrem entre a indicação integral e a aprovação das indicações. Outro aspecto em Duverger é o fator explicativo sobre a categoria simpatizante partidário. Trata-se de um tipo que se encontra na gênese do engajamento entre o cidadão e o partido, contribuindo para entender a formalização do acesso do/a eleitor/a como adepto/a ou filiado/a e sua intrínseca ligação com a estrutura partidária. Os critérios de adesão são: inscrição regulamentada com apadrinhamento e decisão partidária; contribuição financeira; cumprimento das normas e disposição para obedecê-las; critérios constantes do estatuto partidário ${ }^{1}$. Os tipos de filiados/as são: os estáveis e os sazonais, ou instáveis, ou seja, aqueles que mantêm atividades e participação efetiva no partido e aqueles que surgem visando à competição eleitoral (ibidem). Não há referência desse autor à situação das mulheres, com sua ênfase na tecnologia partidária do processo seletivo tomando uma dimensão genérica.

\section{A Presença do Gatekeeper no Modelo de Norris e Lovenduski}

A estrutura do recrutamento ${ }^{2}$ de candidaturas, na versão de Norris (1996), recebe o impacto de três fatores: a) os sistemáticos e do contexto geral do país, em que as circunstâncias do processo são estabelecidas pelo sistema político em regulações do sistema legal, do sistema eleitoral (variáveis contextuais) e do sistema partidário; b) os internos do contexto, com as regras do jogo sendo determinadas no interior dos partidos, o que leva ao necessário conhecimento do sistema partidário, de sua estrutura, poder, ideologia e cultura; c) os específicos, que influenciam o recrutamento de candidatos individuais, ou seja, recursos e motivação de aspirantes (nível da oferta) e a atitude do gatekeeper, ou "porteiro" / selecionador (nível da demanda), podendo comparar quem consegue ser selecionado, por que e quem seleciona. Esses fatores estruturam as oportunidades dos pretendentes aos cargos parlamentares contidas nas regras dos sistemas legal, eleitoral e partidário que determinam as barreiras, além de custos e benefícios, para quem aspira candidatar-se.

O padrão de cidadania dos indivíduos (uma exigência quase universal) é definido pelo sistema legal, que determina os direitos políticos e 
a soberania popular exercida pelo sufrágio universal; pelos critérios de alistabilidade e elegibilidade eleitoral (nacionalidade e idade); e pelas incompatibilidades que se tornam as barreiras para o acesso à elegibilidade ${ }^{3}$. O sistema legal regula o processo de recrutamento de candidaturas na maioria dos sistemas democráticos, majoritários ou proporcionais, por meio dos partidos ${ }^{4}$.

Os sistemas eleitorais têm variação limitada, sendo alguns mais adotados por um número maior de países do que outros. Três fatores influem no recrutamento dos/as candidatos/as no interior desses sistemas e afetam a representação das mulheres: a) a estrutura do voto (se majoritário ou proporcional); b) a magnitude do distrito (número de cadeiras por distrito); c) o grau de proporcionalidade (alocação de votos por assentos). O primeiro fator, diretamente relacionado a este estudo, evidencia o tipo de lista eleitoral utilizado nos sistemas proporcionais, sendo que, na lista aberta, a relação nominal de candidatos/as apresentada pelos partidos é definida pelos eleitores, focando as qualidades individuais dos/as competidores/as. Já na lista fechada, é controlada pelo partido, que ordena previamente os nomes dos/as candidatos/as, e os eleitores votam exclusivamente na legenda. Nos sistemas majoritários, a seleção partidária é de um único candidato por distrito. Norris e Lovenduski (1995:194) consideram os sistemas proporcionais de lista, seguidos dos sistemas mistos, mais do que os majoritários, favoráveis à seleção e à eleição de mulheres, estando todas as condições constantes.

Nas democracias liberais, o sistema partidário é o principal "porteiro" em um processo de recrutamento de candidaturas. Regidos institucionalmente por regras internas (estatutos), os partidos vertebram as relações entre os órgãos decisórios e os/as filiados/as, os procedimentos eleitorais e o processo de seleção de candidatos/as, definindo-se a natureza democrática interna dos partidos e as regras controladoras da entrada dos que aspiram a um assento no Parlamento, cujas decisões são tomadas por líderes nacionais, membros da base partidária e/ou dirigentes locais. Esse processo decisório é complexo, visto que, de certa forma, todos os participantes representam algum papel no recrutamento, variando quanto ao grau de institucionalização e de centralização, com regras formais e informais e decisões centralizadas ou localizadas. Resultam quatro combinações: quando a seleção de candidatos é controlada pela elite partidária central, decidindo por meio de barganha entre si e as facções internas, diz-se que o recrutamento é centrali- 
zado informal. Nesse caso, as regras são simbólicas e os membros partidários representam um frágil papel em uma organização sem tradição democrática. Nesse sistema,

se os líderes partidários são simpáticos à necessidade de promover a igualdade de gênero, por exemplo, se eles desejam atrair mais mulheres eleitoras, eles têm considerável poder para fazê-lo. Através da patronagem, eles podem melhorar a posição das mulheres nas listas partidárias ou lugares em bons distritos (Lovenduski e Norris, 1993:323).

No entanto, ao contrário, se eles não desejam essa promoção da mulher, então podem bloquear-lhe as oportunidades. Quando a decisão sobre quais candidatos entram na lista partidária é da chefia nacional ou executiva que tem autoridade constitucional para isso ${ }^{5}$, diz-se que o recrutamento é formalmente centralizado. $\mathrm{O}$ mais comum entre os partidos liberais é o recrutamento localizado formal, que estabelece diretrizes normativas nos âmbitos nacional e estadual para a padronização do processo, podendo resultar em eqüidade e justiça para com os pretendentes, porque as regras devem determinar a transparência nas escolhas. Essa estrutura de decisões é tomada, grandemente, em nível do distrito eleitoral, com os órgãos regionais também tendo parte na representação. No recrutamento localizado informal, é o distrito local que determina os procedimentos gerais da seleção e a decisão final da escolha individual de candidatos, e "repousa nas mãos de cada eleitorado partidário local, e não há regras partidárias padronizadas interessando o processo de indicação ou revisão da lista partidária global [...]" (ibidem). Esse tipo está exemplificado pela seleção em eleições primárias (abertas) e os Estados Unidos se encontram nesse caso.

O recrutamento é influenciado por fatores individuais que têm funções específicas internas nos processos de oferta e de demanda de candidatos. A oferta é explicada pelo desejo de os aspirantes se lançarem na carreira política, oferecendo seus nomes para concorrerem. Os fatores motivacionais (impulso, ambição e interesse) e o capital político (recursos que trazem para o processo, como tempo, dinheiro, experiência, conexão política) estimulam os/as aspirantes à competição eleitoral. A demanda ou procura por candidatos/as relaciona diretamente o aspirante aos que selecionam, determinando critérios apropriados à escolha de aspirantes aos cargos políticos, dentro de um padrão que garanta a lógica do mercado. A seleção depende então da percepção do "porteiro" (gatekeeper) quanto aos recursos dos aspirantes em habilidades, experiências e qualificação. Essa percepção pode conter, entretan- 
to, níveis de discriminação que permearão o processo de escolha. Norris e Lovenduski (1995) relacionam dois tipos de discriminação no mercado político: a direta e a imputada. A direta é percebida por meio de um julgamento positivo ou negativo de pessoas, com base em características consideradas comuns para seu grupo, e não para os indivíduos, levando estes a serem julgados por suas características de grupo, quando o gatekeeper tem baixas informações sobre ele. A imputada favorece certa categoria de candidatos, mas, como há sempre baixa demanda, eles não são escolhidos, porque a expectativa é a de que não atraiam votos. Nesse caso, há dificuldades para as mulheres, haja vista que, além do peso cultural que as afasta dos degraus de acesso à competição, há a tradição de os "porteiros" escolherem os homens pela demonstração destes nos serviços partidários, entre outros afazeres.

Oferta e demanda interagem. Aspirantes que buscam um cargo elegível podem ser desencorajados a competir por líderes partidários, ao perceberem que tal pretendente pode trazer prejuízos. O grau dessa interação é pouco visível, pois é um "modelo de sistema que produz uma curva fechada de retroalimentação para o retorno do resultado para o grupo daqueles que aspiram a uma carreira política" (ibidem:15) ${ }^{6}$.

\section{O Selectorate no Modelo de Reuven Hazan}

A seleção de candidaturas é uma função primordial dos partidos e nem sempre evidencia com clareza os estágios do processo. O modelo de Hazan (2002) apresenta quatro dimensões: a candidatura; o selectorate; a descentralização; e o mecanismo de votar versus nomear (ou indicar). Essas dimensões são explicativas conforme o continuum dos níveis de inclusão e de exclusão da base do selectorate. A candidatura é o pólo da inclusividade e estabelece que todo/a cidadão/ã eleitor/a pode ser elegível. O selectorate é o órgão selecionador de candidatos/as cuja composição varia de uma pessoa, várias ou de um eleitorado, podendo ser representado por um único líder de partido e pelas agências partidárias cujas dimensões estabelecem a soma de inclusiveness (inclusividade) ou de exclusiveness (exclusão) com que os selecionadores são classificados. Por exemplo, as Convenções são mais amplas do que os comitês centrais e estes são maiores do que os órgãos executivos. A descentralização encerra seu oposto, a centralização, conforme o tipo de selectorate determinado em sua composição (um, vários ou muitos) por selecionadores partidários locais, grupos sociais intrapartidários ou grupos sectários. Pode ser uma descentralização territorial (quando os 
selecionadores são locais, comitês de filiação partidária, membros partidários ou eleitores em distrito eleitoral) ou incorporada (ao assegurar representação funcional a grupos sindicais, de mulheres, minorias, entre outros). As cotas para mulheres exemplificam a descentralização incorporada; e o processo de seleção via eleição versus indicação determina os diferenciais da posição de controle sobre a lista partidária. No primeiro caso, nenhum selectorate poderá mudar essa posição; já no segundo, pode haver mudanças. Para Hazan (ibidem), a estrutura de análise de qualquer método de seleção de candidato deve centrar-se em um país particular e em dado momento específico, com isso dificultando as generalizações por ser desconhecida a base do modelo de seleção.

Esse autor extrai duas generalizações dos tipos de candidato que são produzidos pelos vários métodos de seleção: os que têm as melhores e/ou as piores chances de serem escolhidos. Entre os primeiros encontram-se os do sexo masculino que buscam reeleição (titulares que já têm um perfil diferente dos aspirantes porque já se encontram no ambiente político e podem ser selecionados novamente); entre os segundos estão as mulheres, que já entram no sistema de seleção em desequilíbrio, daí se submetendo à descentralização incorporada - sistema de cotas.

Esses dois modelos transnacionais de seleção de candidatos demonstram uma função partidária com recursos definidores da competição eleitoral, mas pouco visíveis nos estudos sobre os partidos e as eleições no espectro brasileiro. Por considerar que há significativa interligação entre a atitude de "fazer candidatos/as" e a ação de competir por um cargo parlamentar, examinando outras variáveis pertinentes no processo - o peso dos antecedentes sociais e a trajetória pessoal de aspirantes a esses cargos na elaboração da lista partidária -, reitera-se a convicção de que, nesse aspecto, é preciso avaliar como é conduzida a seleção das mulheres filiadas partidárias que aspiram competir.

\section{AS REGRAS NA ESCOLHA DE CANDIDATOS E CANDIDATAS NO SISTEMA POLÍTICO BRASILEIRO}

\section{As Leis Formando a Cidadania Política e Eleitoral}

Avaliando o processo de competição eleitoral no sistema político brasileiro, verifica-se que há regras, inscritas nas constituições e nas leis eleitorais que foram sendo elaboradas desde o Império até a República 
(Álvares, 2004), para que o cidadão e a cidadã se tornem eleitores e elegíveis. Nesses códigos, vértebras da participação e da representação política nacional pela formação de partidos e da justiça eleitoral, há clara exclusão da cidadania política das mulheres. Para romper essa discriminação contida nas leis, elas abriram espaço na educação e na profissionalização e também provocaram uma revisão do Código Civil, que as submetia às práticas de um discurso tradicional e subsidiava as normas vertidas nas leis eleitorais vigentes. Gradualmente, os obstáculos à sua participação política foram cassados por meio das denúncias e da intervenção dos movimentos feministas e de mulheres letradas, além de alguns parlamentares sensíveis à questão, que exigiram a reformulação das leis e a garantia constitucional dos direitos das mulheres. O autoritarismo e a democracia alternaram-se nos anos republicanos brasileiros, dando margem a surtos de mudança nas regras eleitorais, com as mulheres sendo gradualmente qualificadas na condição de eleitoras e de elegíveis.

Embora em 1932 o novo Código Eleitoral, o primeiro vigente no país, registrasse mudanças para a representação proporcional, para o voto universal e direto, e para o sufrágio feminino, o direito de voto concedido às mulheres era facultativo e seletivo. Na redação do anteprojeto desse Código, segundo Porto (2002:238-239), as eleitoras estão referidas de acordo com duas características: o estado civil e a dependência econômica relacionada ao estado civil, demonstrando a forte conexão com o casamento e com a ocupação exercida de forma livre, mas sob a autorização do marido para qualquer "profissão lícita". Essa redação do anteprojeto não foi incorporada, mas o Código Eleitoral manteve as restrições, somente podendo votar as mulheres que exercessem profissões lucrativas.

Mesmo que a partir desse período se observem algumas eleitoras, raras candidatas e, ainda mais, raras eleitas, as restrições legais permaneciam nas cláusulas eleitorais, aliando-se ao ranço secular da exclusão da cidadania política feminina. Na Constituinte de 1933, poucas mulheres fizeram seu registro eleitoral. No Rio de Janeiro, na sede do ativismo sufragista que se articulava mais agressivo desde 1922, somente $15 \%$ dos eleitores filiados eram mulheres. Nesse período, a Federação Brasileira pelo Progresso Feminino criou a Liga Eleitoral Independente, que se propunha a promover a educação política das mulheres e apresentar candidatas. No entanto, nenhuma das sufragistas da Federação se elegeu para a Câmara dos Deputados, salvo Bertha Lutz, 
que ficou na suplência da paulista Carlota Pereira de Queiroz, a primeira mulher eleita para a Câmara dos Deputados não associada ao movimento. O desenho de um quadro eleitoral e partidário sem o efetivo feminino trouxe marcas acentuadas da cultura política dicotômica entre homens e mulheres. Nas discussões da Constituição de 1934, dois movimentos sufragistas da época, a Federação Brasileira pelo Progresso Feminino, presidida por Bertha Lutz, e a Aliança Nacional de Mulheres, dirigida por Natércia da Silveira, prestaram ampla contribuição para a reformulação dessas restrições.

Os dispositivos de exclusão da cidadania política às mulheres, constando das leis eleitorais anteriores, que seletivamente afastavam da cidadania ativa e passiva as "que não exerciam profissão lucrativa" (arts. 5o e 6o), somente deixaram de constar do Código Eleitoral em 1965, promulgado pelos militares na Quarta República (1964-1985). Também pela primeira vez há referência à necessidade de filiação partidária do aspirante ao cargo eletivo e outras cláusulas a serem observadas pelo candidato ${ }^{7}$ para ser incluído na lista partidária.

Quanto à indicação de candidatos/as, até 1995 o sistema eleitoral brasileiro era regulamentado pela Lei no $5.682 / 71$, sendo um processo uniforme entre todos os partidos. Com a Lei no 9.096/95, excluiu-se da legislação nacional o processo de indicação de candidatos, formalizando-se esse procedimento nos estatutos dos partidos ${ }^{8}$. No Capítulo III Do Programa e do Estatuto-, o art. 15, ao enfatizar o conteúdo normativo partidário (filiação, direitos e deveres dos membros, fidelidade e disciplina partidária), dispõe, em seu item VI, sobre as "condições e forma de escolha de seus candidatos a cargos e funções eletivas". Nota-se a ênfase no processo de escolha de candidatos/as, estabelecido na formalização dos princípios e das normas de conduta a serem seguidas pelo/a filiado/a, figura que se efetiva quando os partidos se regularizam. Na Justiça Eleitoral ${ }^{9}$, os filiados crescem de importância ao assumir incumbências formais, administrativas, integram-se às atividades sob sua competência, postos determinados nos degraus intrapartidários e ainda com possibilidade de eleger-se parlamentar ou outro cargo de seu interesse.

Os arranjos de filiação partidária e as cláusulas sobre disciplina, direitos e deveres dos/as filiados/as têm precedência entre os demais assuntos estatutários, visto ser a forma de caracterizar os membros do partido e classificá-los em setores de direção e ação. A idade de um/a 
filiado/a está entre 16 e 18 anos, de nacionalidade brasileira, gozando os direitos políticos e comprometido/a com o programa e com o estatuto do partido. A condição de votar e ser votado (para os órgãos partidários ou para cargos eletivos) é o requisito estatutário comum a todos/as e a garantia de aspirarem a uma carreira política.

Na Figura 1, pode ser percebida a escada cujos degraus um eleitor ou eleitora (que esteja no gozo de seus direitos políticos) deve subir se aspira a um cargo eletivo. Vale dizer que são estes os passos do aspirante no processo que formaliza a inscrição do/a filiado/a como membro partidário.

\section{Os/as Filiados/as Partidários/as no Brasil}

O atributo de alistável garante a participação do cidadão ou cidadã em uma eleição como eleitor ou eleitora, mas, para concorrer a um cargo eletivo, terá de estar filiado/a a um partido. Essa prática é circunstanciada pela engenharia institucional dos órgãos partidários para sensibilizar simpatizantes, criar adeptos e transformá-los em candidatos potenciais, seguir algumas normas básicas estatutárias, ser pré-selecionado e indicado por outro membro do partido ou agência partidária investido da função de selecionador, com o nome do selecionado constando da lista final homologada em Convenção.

Figura 1

Escada de Acesso do/a Eleitor/a ao Cargo Eletivo

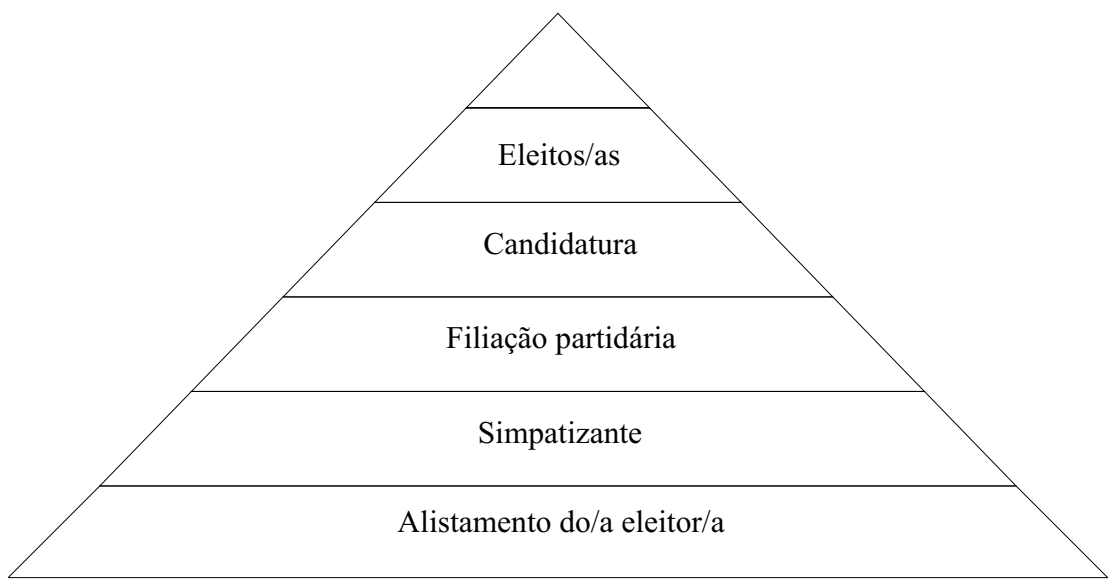

Elaboração da autora com base na literatura explorada. 
Considerando esse processo, é pertinente a visão do quadro geral do eleitorado brasileiro distribuído entre os percentuais de filiados/as e não filiados/as e o total de eleitores. Na Tabela 1, estão computados os registros das eleições de 2002.

Tabela 1

Distribuição, por Sexo, do Total de Filiados e Não Filiados*

\begin{tabular}{l|cc|cc|cc|cc}
\hline Situação & \multicolumn{2}{|c|}{ Mulher } & \multicolumn{2}{|c|}{ Homem } & \multicolumn{2}{|c|}{ Não Informado } & \multicolumn{2}{|c}{ Total } \\
& Abs & $\%$ & Abs & \% & Abs & \% & Abs & \% \\
\hline Não filiados & 53.898 .570 & 91,8 & 49.843 .263 & 88,9 & 177.366 & 85,4 & 103.919 .199 & 90,3 \\
Filiados & 4.827 .159 & $\mathbf{8 , 2}$ & $\mathbf{6 . 2 4 4 . 4 0 3}$ & $\mathbf{1 1 , 1}$ & $\mathbf{3 0 . 3 2 7}$ & $\mathbf{1 4 , 6}$ & $\mathbf{1 1 . 1 0 1 . 8 8 9}$ & $\mathbf{9 , 7}$ \\
Total de eleitores & 58.725 .729 & 100,0 & 56.087 .666 & 100,0 & 207.693 & 100,0 & 115.021 .088 & 100,0 \\
\hline
\end{tabular}

Fonte: Dados do TSE/Tribunal Regional Eleitoral - TRE-PA.

* Filiados até julho/2002.

Em estudos comparados de Mair e Biezen (2001), para verificar os níveis de filiados individuais de partidos políticos em vinte democracias européias contemporâneas, os autores demonstraram que, nos anos 1990, houve declínio significativo dos/as filiados/as partidários/as nesses sistemas. A Áustria, que em 1980 apresentava um quadro de 28,48\% de membros, em 1999 rebaixa esse percentual para 17,66\%.

$\mathrm{O}$ fato de o/a filiado/a ser um agente importante no estabelecimento do fundo partidário que sustenta as campanhas eleitorais nesses países se revela uma vertente da discussão atual no questionamento sobre a veracidade ou não dos números registrados. A dúvida recai na suposição de que as lideranças partidárias precisam confirmar uma ampla massa de adeptos na base para o reconhecimento de sua legitimidade na sociedade e, por isso, eles tendem a declarar uma política ativa no engajamento de cidadãos, visto que os/as filiados/as são considerados/as a fonte dessa legitimidade tanto dentro quanto fora dos partidos.

Nessas vinte democracias, a média de filiados/as foi de $4,99 \%{ }^{10}$. Isso quer dizer que o quadro de filiados partidários no Brasil se encontra em uma boa posição, equivalendo-se à Polônia, que tem 9,65\% de membros. A identificação partidária dos/as filiados/as brasileiros/as em 2002 é mostrada na Tabela 2, classificando-se do maior para o menor percentual de mulheres filiadas.

Há estudos que apontam a maior presença das mulheres eleitas nos partidos de esquerda e em partidos novos (Matland, 2002; Htun, 2002). 
Tabela 2

Distribuição dos Filiados por Sexo e Partido

Brasil - 20021

\begin{tabular}{|c|c|c|c|c|c|c|c|c|}
\hline \multirow[b]{2}{*}{ Partido } & \multicolumn{2}{|c|}{ Mulher } & \multicolumn{2}{|c|}{ Homem } & \multicolumn{2}{|c|}{ Não Informado } & \multicolumn{2}{|c|}{ Total Geral } \\
\hline & Abs & $\%$ & Abs & $\%$ & Abs & $\%$ & Abs & $\%$ \\
\hline PSTU* & 6.379 & 49,3 & 6.524 & 50,5 & 27 & 0,2 & 12.930 & 0,1 \\
\hline РCB & 4.823 & 48,9 & 5.006 & 50,8 & 27 & 0,3 & 9.856 & 0,1 \\
\hline PC do B & 72.115 & 47,3 & 79.896 & 52,4 & 409 & 0,3 & 152.420 & 1,4 \\
\hline PT do B & 40.869 & 46,9 & 45.975 & 52,8 & 277 & 0,3 & 87.121 & 0,8 \\
\hline $\mathrm{PCO}$ & 751 & 46,3 & 867 & 53,5 & 4 & 0,2 & 1.622 & 0,0 \\
\hline PTC & 50.469 & 46,3 & 58.364 & 53,5 & 275 & 0,3 & 109.108 & 1,0 \\
\hline Prona & 13.836 & 46,1 & 16.048 & 53,5 & 97 & 0,3 & 29.981 & 0,3 \\
\hline PRP & 69.445 & 45,8 & 81.802 & 53,9 & 458 & 0,3 & 151.705 & 1,4 \\
\hline PMN & 67.544 & 45,7 & 79.806 & 54,0 & 439 & 0,3 & 147.789 & 1,3 \\
\hline PSL & 45.634 & 45,6 & 54.221 & 54,2 & 266 & 0,3 & 100.121 & 0,9 \\
\hline PHS & 19.282 & 45,4 & 23.085 & 54,4 & 68 & 0,2 & 42.435 & 0,4 \\
\hline PSC & 91.093 & 45,4 & 108.814 & 54,3 & 625 & 0,3 & 200.532 & 1,8 \\
\hline PSDC & 24.825 & 44,9 & 30.325 & 54,8 & 144 & 0,3 & 55.294 & 0,5 \\
\hline PL & 274.227 & 44,5 & 340.530 & 55,2 & 1.629 & 0,3 & 616.386 & 5,6 \\
\hline PTN & 15.864 & 44,2 & 19.929 & 55,5 & 87 & 0,2 & 35.880 & 0,3 \\
\hline PMDB & 963.408 & 44,0 & 1.219 .290 & 55,7 & 6.992 & 0,3 & 2.189 .690 & 19,7 \\
\hline PSB & 153.089 & 43,9 & 194.728 & 55,8 & 971 & 0,3 & 348.788 & 3,1 \\
\hline PRTB & 16.474 & 43,7 & 21.117 & 56,1 & 74 & 0,2 & 37.665 & 0,3 \\
\hline PAN & 13.478 & 43,7 & 17.280 & 56,0 & 79 & 0,3 & 30.837 & 0,3 \\
\hline PSDB & 463.883 & 43,6 & 596.818 & 56,1 & 2.632 & 0,2 & 1.063 .333 & 9,6 \\
\hline $\mathrm{PP}^{2}$ & 600.956 & 43,5 & 775.305 & 56,2 & 3.715 & 0,3 & 1.379 .976 & 12,4 \\
\hline РТВ & 450.539 & 43,4 & 583.737 & 56,3 & 3.164 & 0,3 & 1.037 .440 & 9,3 \\
\hline PV & 42.540 & 43,4 & 55.293 & 56,4 & 226 & 0,2 & 98.059 & 0,9 \\
\hline PDT & 413.140 & 43,3 & 538.676 & 56,4 & 2.582 & 0,3 & 954.398 & 8,6 \\
\hline PFL & 429.030 & 41,7 & 596.849 & 58,1 & 2.206 & 0,2 & 1.028 .085 & 9,3 \\
\hline PPS & 125.723 & 41,2 & 178.424 & 58,5 & 739 & 0,2 & 304.886 & 2,7 \\
\hline $\mathrm{PT}$ & 357.743 & 40,9 & 515.694 & 58,9 & 2.115 & 0,2 & 875.552 & 7,9 \\
\hline Total geral & 4.827.159 & 43,5 & 6.244 .403 & 56,2 & 30.327 & 0,3 & 11.101.889 & 100 \\
\hline
\end{tabular}

Fonte: TSE/TRE-PA.

${ }^{1}$ Filiados até julho/2002.

2 Antigo PPB.

*Ver lista de siglas dos partidos políticos, com os respectivos significados, no final deste artigo. 
No caso deste artigo, essa presença foi avaliada no estágio das filiações partidárias entre blocos ideológicos ${ }^{11}$ e entre os partidos configurados em tamanho ${ }^{12}$ para identificar qual deles teve um percentual significativo de mulheres na base partidária antes da competição ${ }^{13}$. Assim, tomando o bloco ideológico e o percentual de filiação, em 2002 foi verificado que, entre os partidos da direita (grandes, médios e nanicos), PT do B, PTC, Prona, PRP, PMN, PSL, PHS, PSC, PSDC, PTN, PRTB e PAN exibem percentuais significativos de filiação de mulheres com uma variação em relação à filiação masculina entre $-5,9 \%$ e $-12,3 \%{ }^{14}$. Os que têm maior número de filiados/as, como PFL, PP e PTB, apresentam percentuais diferenciais de $-16,3 \%,-12,6 \%$ e $-12,8 \%$, respectivamente, para as filiações de mulheres. Os partidos de direita são os que mais contribuem percentualmente com o total de filiados brasileiros: 45,9\%.

Entre os três partidos que representam o bloco de centro, o percentual de variação de filiações de mulheres em relação aos homens está entre $-11,7 \%,-12 \%$ e $-13,1 \%$, apontando um nível de equilíbrio de variação entre eles. O PMDB registra maior percentual de mulheres filiadas. Esse bloco contribui com 37,9\% do total de filiados brasileiros.

No bloco de esquerda, PCB, PSTU e PCO registraram maior percentual de filiadas, quer como interblocos, quer como intrablocos. Os partidos com estrutura estável, como PT, PSB e PPS, têm maiores percentuais de homens entre seus filiados, com o primeiro apresentando quase $60 \%$ de seu quadro partidário masculino. O bloco contribui com 16,3\% do total de filiados/as.

No período de formação do PT, as mulheres filiadas empreenderam uma forte luta para garantir seu lugar entre os membros dirigentes. Borba, Faria e Godinho (1998) argumentam que, à medida que o partido se organizava, elas perdiam espaço. As mudanças para o incremento da presença das mulheres nos órgãos de direção, exclusivamente masculino, dependeram de intensa luta para a inclusão, entre as disposições estatutárias, dos $30 \%$ de mulheres entre os dirigentes, ocorrendo formalmente em 1991, com a presença significativa de mais mulheres.

No processo de filiação partidária, há outros fatores que podem explicar a tendência do eleitorado a se constituir em simpatizante ou não do partido para o avanço nesse degrau de acesso. Evidenciando o programa e a ideologia partidária, Bey-Ling Sha (2003) analisou o Democratic Progressive Party - DPP, o principal partido da oposição em Taiwan, demonstrando a dificuldade do engajamento da eleitora como simpa- 
tizante e membro do partido, porque as mulheres resistiam às informações que tinham dele - "provocativo e violento".

O argumento de Inglehart e Norris (2003b) trata das barreiras culturais de determinadas sociedades que explicam as atitudes tradicionais para a igualdade de gênero, influenciando o nível de avanço (alto ou baixo) das mulheres para os cargos eletivos, que podem estar em estágios anteriores, como o de não-simpatizantes e, portanto, não-adeptas ao programa do partido: "Em culturas com valores tradicionais sobre o papel da mulher no lar e família, muitas mulheres podem se recusar a concorrer e, se elas procuram um cargo, elas podem deixar de atrair apoio suficiente para vencer" (ibidem:133; tradução da autora).

Em todo caso, a situação das mulheres nos partidos brasileiros merece uma atenção maior. Se compararmos os $40 \%$ de filiadas ao percentual masculino, há desnível, mas não se pode dizer que esse valor seja inexpressivo. O problema está na passagem de filiadas para as listas partidárias de candidaturas.

No estágio de entrada das mulheres na representação parlamentar, alguns partidos mantêm regras estatutárias aos degraus de acesso. $\mathrm{O}$ percentual de filiados/as partidários/as brasileiros/as se encontra no mesmo nível dos partidos das democracias ocidentais (Mair e Biezen, 2001); e o percentual de $40 \%$ de mulheres filiadas é bastante significativo no quadro nacional.

\section{A presença do "selecionador" nos estatutos partidários: avaliando um "degrau" de acesso às candidaturas}

O sistema democrático representativo se legitima pelo consenso verificado por meio de eleições livres e do sufrágio universal, sendo os atores principais nesse sistema os partidos políticos e os cidadãos e cidadãs que participam, quer com direito a se eleger, quer com direito a eleger outrem para um determinado cargo político em um período específico.

Os partidos políticos têm papel fundamental na organização do ingresso do/a cidadão/ã na vida política (como eleitor/a e aspirante ao cargo eletivo) de um país. Duverger (1970) tratou do assunto em regimes de democracia representativa evidenciando os enfoques da seleção diferenciada entre os tipos de partido e a relação entre pré-escrutínio (pré-seleção) e designação de candidatos, observando a variabili- 
dade do grau de intervenção dos partidos e a sutileza que é usada na relação entre estes e os concorrentes na ratificação dos nomes, oficializada pelas organizações partidárias, e nas negociações que ocorrem entre a indicação e a aprovação dessas indicações.

No Brasil, o papel dos partidos políticos na organização das demandas institucionais (representação nos órgãos da Justiça Eleitoral e na legislação eleitoral) para o ingresso do cidadão na vida política (eleitor e elegível) teve maior destaque com a criação da Lei Agamenon ( $\mathrm{n}$ o 7.586/45), que exigiu o registro dos partidos em bases nacionais, confirmada pela Constituição de 1946. A indicação de candidatos/as como um processo uniforme entre todos os partidos foi regulamentada pela Lei no 5.682/71, e a Lei no 9.096/95 deslocou essa função para os estatutos partidários.

Para verificar a existência de critérios que possibilitam reconhecer um tipo de "selecionador" de candidaturas, ou quem está qualificado pelo partido a preencher essas condições, e para saber quem elabora as listas nominais votadas nas convenções partidárias, foram examinados os estatutos do PT, do PMDB e do PP, escolhidos por critérios históricos, ideológicos e, no caso do primeiro, por fazer constar, entre os itens do documento, um capítulo específico sobre o processo seletivo de candidaturas ${ }^{15}$. Aplicou-se o modelo de Rahat e Hazan (2001) para identificar a função de selecionador entre os membros das várias agências partidárias e a situação de maior/menor inclusão/exclusão desse selecionador ${ }^{16}$. Considera-se, contudo, os diferenciais dos modelos anglo-americanos que subsidiaram esse estudo.

O controle da oferta de candidatos/as aos cargos eletivos do PT (arts. 127 a 134) se dá para os cargos parlamentares e majoritários, distribuídos entre os níveis municipal, estadual e federal, em três ou quatro formas de apoio, segundo a competência da indicação, para posterior encaminhamento à Comissão Executiva.

Considerando a abordagem da literatura internacional sobre a função de votar ou indicar os/as candidatos/as pelo selecionador partidário, no Quadro 1, registra-se o modelo em que o selecionador de candidaturas circula entre a indicação, a votação e a homologação ${ }^{17}$, cada processo centralizado nos membros filiados que detêm cargos do Diretório em níveis nacional (no caso de presidente da República), estadual ou municipal, para os quais foram eleitos, ou em Núcleos de Base municipal ou setorial ${ }^{18}$. 


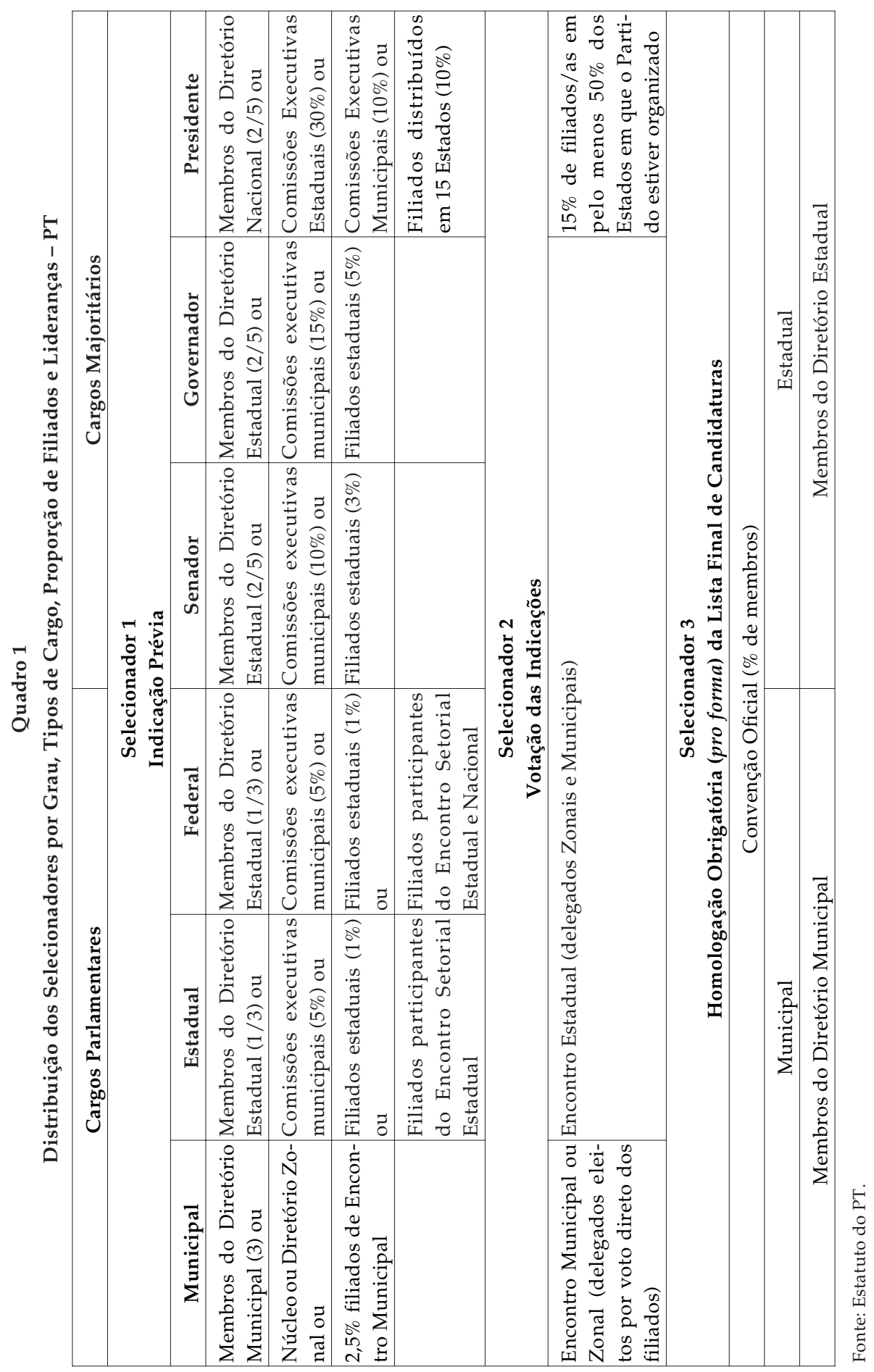


Figura 2

Selecionadores de Candidatos/as pelo Grau de Inclusão - PT

\begin{tabular}{|c|c|c|c|c|}
\hline \multicolumn{4}{|c|}{$\begin{array}{c}\text { Maior } \\
\text { Inclusão }\end{array}$} & $\begin{array}{c}\text { Maior } \\
\text { Exclusão }\end{array}$ \\
\hline \multicolumn{5}{|l|}{4} \\
\hline & $\begin{array}{c}\text { Selecionador } 1 \\
\text { Indicação Prévia }\end{array}$ & $\begin{array}{c}\text { Selecionador } 2 \\
\text { Votação das Indicações }\end{array}$ & $\begin{array}{c}\text { Selecionador } 3 \\
\text { Homologação da } \\
\text { Lista Final de } \\
\text { Candidaturas }\end{array}$ & \\
\hline & $\begin{array}{l}\text { Apoio de mem- } \\
\text { bros eleitos do } \\
\text { partido, qualifica- } \\
\text { dos ou não (indi- } \\
\text { cação interna fe- } \\
\text { chada) }\end{array}$ & $\begin{array}{c}\text { Encontro do partido } \\
\text { (votação por órgãos co- } \\
\text { legiados do partido for- } \\
\text { mado de membros } \\
\text { eleitos) }\end{array}$ & $\begin{array}{l}\text { Congresso Oficial } \\
\text { (homologação } \\
\text { aprovada pelos } \\
\text { membros eleitos } \\
\text { dos diretórios das } \\
\text { circunscrições elei- } \\
\text { torais municipais } \\
\text { ou estaduais } \\
\text { (Convenção) }\end{array}$ & \\
\hline & Estadual Local & Estadual & Estadual Local & \\
\hline
\end{tabular}

Fonte: Estatuto do PT. Elaboração de Álvares (2004) a partir de Rahat e Hazan (2001) e Hazan (2002).

Na Figura 2, a configuração apresenta os estatutos do PT com os tipos de selecionador e os implicados em uma seleção prévia de filiados/as.

A avaliação aponta um processo que evidencia a média inclusão (selecionadores 1 e 2) ao limite médio da maior exclusão (selecionador 3), em se tratando da posição centralizada do selecionador ou nível de democracia interna do partido. Se todos os filiados/as contribuem financeiramente para o partido e têm outros requisitos constantes de seus direitos e deveres estatutários, o mais democrático, ou o nível de maior inclusão, seria que todos tivessem acesso à escolha dos que participam da lista votada na Convenção e apresentada ao eleitorado para ser sufragada, uma vez que os/as eleitos/as passarão a fazer parte da bancada parlamentar ou majoritária do partido.

O PMDB ${ }^{19}$ identifica o selecionador no Capítulo I das Disposições Gerais estatutárias, no art. 109, ao se referir às "eleições prévias para a escolha de candidatos a cargos executivos ou a cargos parlamentares sujeitos ao sistema majoritário". Essas eleições são disciplinadas pela Resolução do Conselho Nacional ${ }^{20}$, sendo o resultado proclamado pela respectiva Convenção. Não há um capítulo específico se referindo a uma pré-escolha de candidatos/as, salvo as atribuições de competên- 


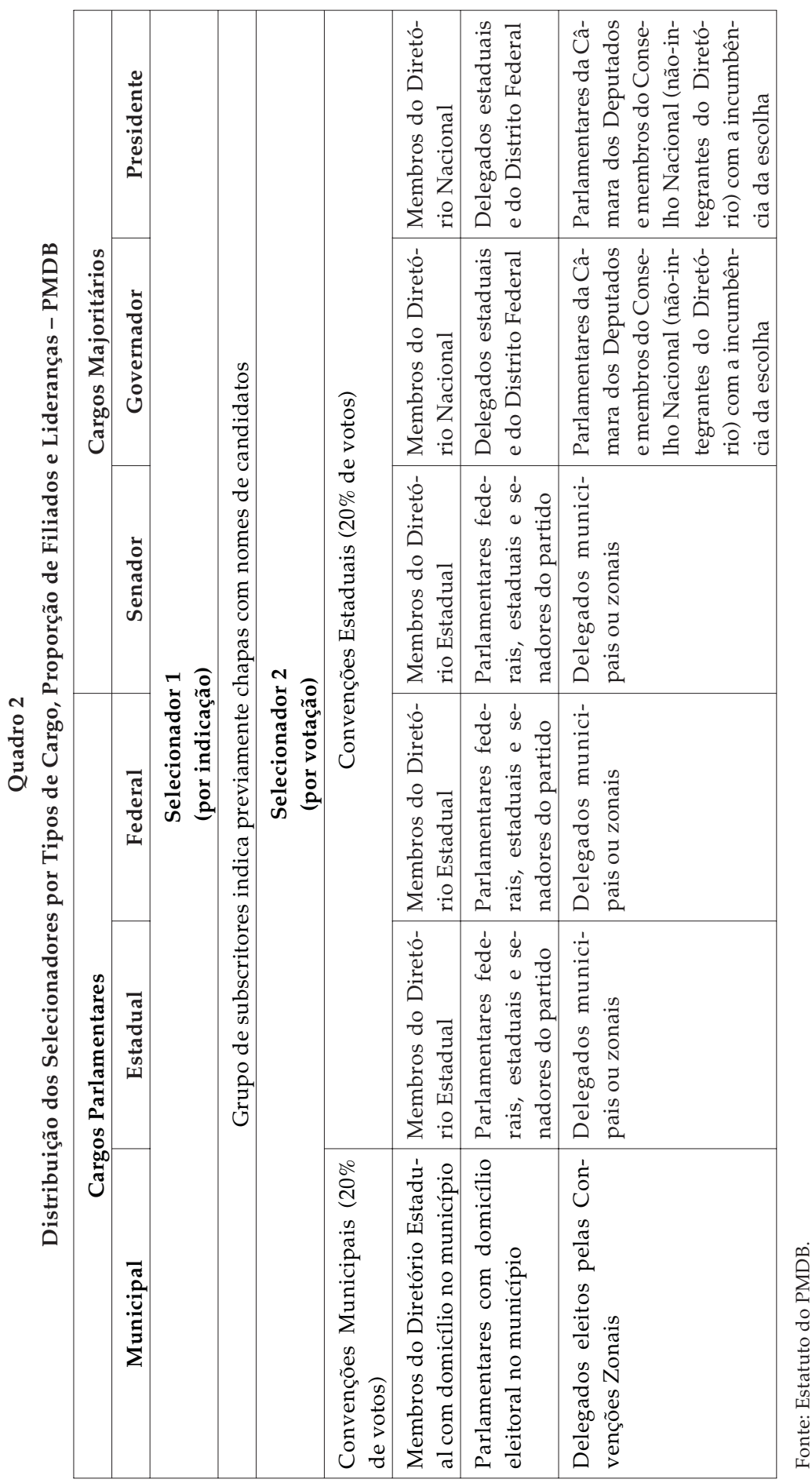


cias das várias agências partidárias (Diretórios Municipal, Estadual e Nacional) em que está evidente o papel da Convenção quanto a escolher e proclamar. As eleições prévias estão sujeitas a uma Resolução do Conselho Nacional, mas nada indica sua efetivação, a exemplo dos estatutos do PT. Outro aspecto dessa escolha prévia é o indicativo de causalidade da situação (quando houver eleição prévia) e não a regularidade do evento, prevalecendo, nesse caso, o papel dos subscritores da lista nominal.

O PMDB apresenta dois tipos de selecionador. Um primeiro consta do art. 23, §§ 1o e 3o, sendo as Convenções o órgão máximo de escolha de candidatos / as para as eleições proporcionais. No caso da existência de somente uma chapa, esta será eleita, em toda a sua composição, se alcançar pelo menos $20 \%$ dos votos dos convencionais. O § 3 o acrescenta que até 48 horas antes do início da Convenção "o grupo de subscritores poderá promover a substituição de nomes na chapa proposta, bem como a fusão de chapas". Isso revela a existência de uma pré-seleção de nomes compondo uma lista elaborada por membros partidários que previamente indicaram os/as candidatos/as da relação de filiados /as prospectivos e que será submetida à votação na Convenção de cada área. Essa é a primeira esfera do selecionador. A segunda é a votação dos membros partidários e delegados convencionais.

Na Figura 3, o selecionador cuja composição está identificada como um "grupo de subscritores" é considerado o selecionador 1 na célula da maior exclusão porque a seletividade do conjunto pode estar considerando um grupo da elite partidária com destaque nas lideranças, ou uma organização de base com ênfase em movimento setorial, para apresentar uma lista de nomes de candidatos/as. O selecionador 2 é a Convenção; posiciona-se no limite médio da maior exclusão porque, nesse caso, houve uma maior abertura para a presença de delegados de todos os órgãos do partido. Nos dois aspectos, a seletividade faz pensar na exclusão de um maior número de membros apoiadores filiados da base partidária exercendo a indicação, pois não aparece uma explicação logística (cálculo percentual) para garantir o tamanho do selecionador, conforme referido na etapa prévia dos apoiadores de candidaturas do PT.

A média exclusão é a tendência de o selecionador abrir-se para mais filiados/as qualificados/as, ou fazendo parte das agências partidárias, 
Figura 3

Selecionadores de Candidatos/as pelo Grau de Inclusão - PMDB

\begin{tabular}{l|l|c|c}
\hline $\begin{array}{c}\text { Maior } \\
\text { Inclusão }\end{array}$ & & $\begin{array}{c}\text { Selecionador 2 } \\
\text { Homologação via vo- } \\
\text { tação da lista final de } \\
\text { candidaturas }\end{array}$ & $\begin{array}{c}\text { Maior } \\
\text { Exclusão }\end{array}$ \\
\hline & & Convenção & $\begin{array}{c}\text { Selecionador 1 } \\
\text { Cordicação prévia }\end{array}$ \\
\hline & & $\begin{array}{c}\text { Grupo de subscritores indicam } \\
\text { previamente chapas com nomes } \\
\text { de candidatos }\end{array}$ \\
\hline
\end{tabular}

Fonte: Estatuto do PMDB. Elaboração de Álvares (2004) a partir de Rahat e Hazan (2001) e Hazan (2002).

ou que assumiram postos internos (membros do Diretório, da Executiva etc.) por via de eleição.

A conclusão a que se chega é a de que o PMDB apresenta um processo de seleção tendente a um modelo de indicação, votação e homologação cujo primeiro estágio está centrado em apoiadores sem identificação definida nos artigos estatutários; já o segundo e o terceiro são estabelecidos pelos filiados delegados da Convenção.

O estatuto do $\mathrm{PP}^{21}$ apresenta as competências dos membros do partido desde a condição de fundadores efetivos e beneméritos até a escolha de candidatos / as na Convenção em cada área (nacional, municipal e estadual), adotando duas fórmulas - indicar e escolher - que têm alguma importância na análise política. O fato de o selecionador ao cargo majoritário de presidente e vice se constituir por meio de uma indicação, via Convenção Nacional, implica uma deferência elitizada se comparada ao a plicado no processo para os demais cargos. Há também o fato de as implicações políticas sobre esse cargo refletirem indicações por lideranças regionais, além de a avaliação pela cúpula nacional considerar a inviabilidade da indicação. Isso aponta para o centralismo da tomada de decisões no partido.

O processo de escolha de candidatos / as não está em um item específico, mas há indicação da formação de chapas partidárias às eleições proporcionais no art. 115, § 1ㅇdas Disposições Especiais, quando trata dos movimentos de apoio $^{22}$. 
Mulheres Brasileiras em Tempo de Competição Eleitoral...

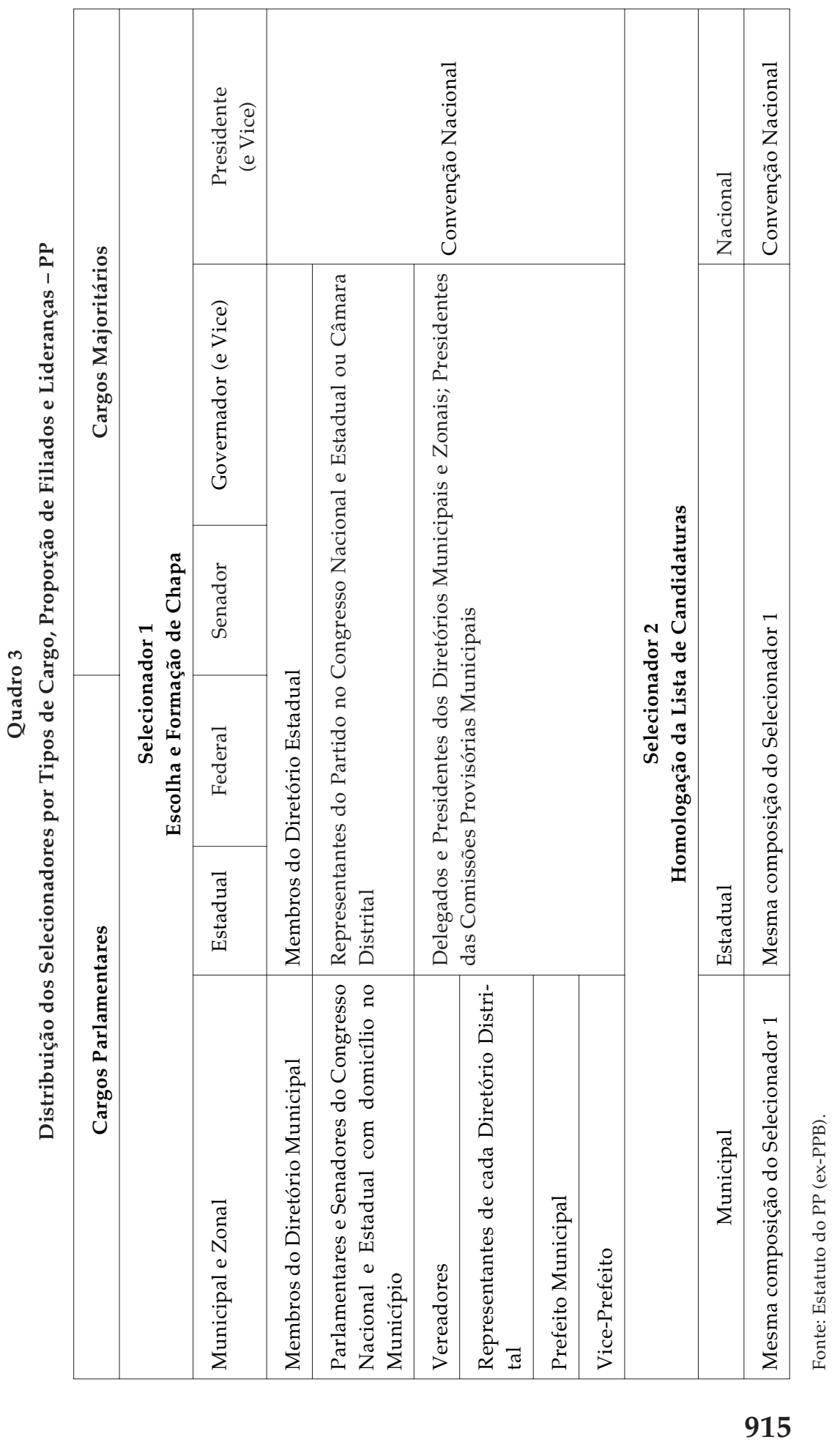


O estatuto do PP tem afinidade com o do PT ao assegurar às mulheres, enquanto integrantes de um órgão de colaboração do partido, tal como os demais movimentos (trabalhadores, juventude), o direito à representação em cada Diretório (arts. 11 a 113) em que estejam organizadas. Enquanto representantes dos Diretórios, os movimentos de apoio, como agências partidárias, fazem parte do selecionador, podendo formar suas chapas e, conforme o prazo estipulado, encaminhar à Executiva do partido para que sejam apresentadas e homologadas na Convenção. O diferencial do PT é que as mulheres fazem parte dos órgãos de direção e de atuação do partido, e não somente dos órgãos de colaboração e de apoio.

A Figura 4 mostra a posição do PP e o grau de inclusão/exclusão do selecionador no processo de escolha de candidatos configurado no modelo de Hazan (2002).

É possível observar que, embora se evidencie controle na indicação de candidatos / as, a relação destes com o partido não é tão forte, apesar da necessidade de formalização da candidatura. O selecionador 1 posiciona-se na célula da maior exclusão e o selecionador 2 encontra-se na célula da média exclusão. No primeiro caso, situam-se membros categorizados do partido; no segundo, há uma dualidade entre selecionadores: os delegados de todos os órgãos do partido homologam as candidaturas parlamentares e algumas majoritárias, mas, ao atuarem na indicação do cargo de presidente e vice, restringem os membros para

Figura 4

Selecionadores de Candidatos/as pelo Grau de Inclusão - PP

\begin{tabular}{l|l|l|l}
\multicolumn{2}{l|}{ Maior Inclusão } \\
\hline \multicolumn{1}{l|}{} & & $\begin{array}{c}\text { Selecionador 2 } \\
\text { Homologação via Votação da } \\
\text { Lista Final de Candidaturas }\end{array}$ & \multicolumn{1}{c}{$\begin{array}{c}\text { Selecionador 1 } \\
\text { Por Indicação Prévia }\end{array}$} \\
\hline & Convenção & $\begin{array}{l}\text { Maior Exclusão } \\
\text { Convenção Nacional indica nomes à } \\
\text { presidência e vice } \\
\text { Grupo de subscritores indica previa- } \\
\text { mente chapas com nomes de candida- } \\
\text { tos/as } \\
\bullet \text { Movimentos de apoio indicam candi- } \\
\text { datos/as }\end{array}$ \\
\hline & Nacional Estadual Local & $\begin{array}{l}\text { Nacional Estadual } \\
\text { Local }\end{array}$ \\
\hline
\end{tabular}

Fonte: Estatuto do PP. Elaboração de Álvares (2004) a partir de Rahat e Hazan (2001) e Hazan (2002). 
os que fazem parte da Convenção Nacional, ocorrendo assim uma exclusão maior desses membros. Há outra perspectiva: a indicação de candidaturas no selecionador 1 se dá por "grupos de subscritores" que podem estar relacionando apenas as lideranças e os dirigentes partidários; e por movimentos de apoio, que, embora tenham uma base social maior para selecionar seus candidatos, são restritos nos percentuais (20\% de lugares a que o partido tem direito) e também na regra de filiação partidária. O grau de média exclusão evidencia a participação de mais filiados / as na Convenção enquanto delegados/as e dirigentes partidários reconhecidos na base do selecionador municipal, estadual e nacional.

Nos três exemplos extraídos do processo formal de indicação de candidaturas, ficou evidente que há regras partidárias que sustentam a oferta e a demanda dos pretendentes aos cargos eletivos, tornando exposta a distribuição do poder no interior da organização partidária nos limites de média e baixa inclusão e de média e alta exclusão.

Embora os estatutos possam dimensionar institucionalmente a pré-escolha de candidatos/as e a aprovação de uma lista nominal na Convenção partidária, a questão levantada relaciona a prática usual, entre os partidos brasileiros, de apoiarem os nomes de filiados / as interessados/as em concorrer ou saídos da indicação de líderes representativos do partido que, prevendo resultados eleitorais satisfatórios, se centram em dois aspectos: a) interesse em aumentar os votos válidos tendo em vista inscrever-se como partidos efetivos, com preenchimento de cadeiras parlamentares; b) incentivo à competição de filiados/as com o preenchimento integral das listas nominais, haja vista a necessidade de comporem a cota partidária para concorrerem, sendo esta bastante elevada. Para as eleições proporcionais, por exemplo, podem registrar até $150 \%$ do número de lugares a preencher (Lei no 9.504/97, art. 10, caput $)^{23}$.

A representação por Estados e pelo Distrito Federal é estabelecida por um número de cadeiras distribuído proporcionalmente à população. Essa cota nem sempre se completa pela demanda e oferta de candidatos/as, e os partidos geralmente inscrevem nas listas os / as filiados / as que, mesmo sem motivação para concorrer, funcionam como "soldados do partido", aceitando indicar seu nome para o preenchimento das vagas abertas. Há também os que são inscritos para o serviço partidário nas eleições (campanhas etc.). Esses procedimentos suscitam algu- 
mas perguntas: se todos os filiados ou filiadas estão aptos a concorrer, qual é o potencial de cada filiado/a ser apresentado (oferta e demanda) na lista do partido? Nesse caso, qual é o potencial das mulheres? ${ }^{24}$

O critério utilizado é o da aceitabilidade dos que querem concorrer, com peso no julgamento informal, implícito e subjetivo, prevendo que cada candidato/a possa dispor da preferência eleitoral para aumentar os votos válidos do partido.

No que pode ser observado, o selecionador não obedece a uma situação de gênero para dispor de suas regras. O degrau de acesso das mulheres ao Parlamento não está sendo impedido por essa via de entrada formal. Se há filiadas oferecendo sua candidatura, elas são incluídas e passam a competir por votos. Há demanda partidária por candidaturas femininas caso os partidos verifiquem a força nominal de uma filiada. Essa é a situação que pode ser avaliada no jogo de formalidades desse primeiro degrau de ingresso das mulheres na competição eleitoral. Não há pré-seleção ou seleção formal de candidaturas femininas.

\section{ACESSO DAS MULHERES AO LEGISLATIVO BRASILEIRO}

\section{As Candidaturas Femininas no Período de 1946 a 1982}

O modelo do sistema eleitoral brasileiro é de representação proporcional de lista aberta apresentando critérios para a distribuição de cadeiras conquistadas pelos partidos entre os candidatos de cada lista com os nomes de filiados / as -, votada em Convenção e apresentada para a competição com o ordenamento nominal sendo feito pelos eleitores ao escolherem seus candidatos/as preferenciais.

Em nível estatutário, a competição eleitoral ocorre dessa forma porém, há outras nuanças subjacentes e pouco evidentes. O avanço da posição de filiado para a condição de aspirante ao cargo eletivo e sua inclusão em uma lista de candidatos apresentam outros percursos - além das atribuições formais de um processo vigendo somente para ratificar os enredos eleitorais nas Convenções e de ser o partido oficialmente inscrito pelos Tribunais Regionais Eleitorais - TREs, na competição do período. Incluem procedimentos de indicação mais frouxos, o que configura o sistema partidário brasileiro como oligárquico (Santos, 1994; Lima Junior, 1983; 1991). Prevalece a composição da lista nominal como arranjo dos dirigentes partidários sem que haja uma consulta direta aos/às filiados/as. Contudo, a Convenção mantém o poder das li- 
deranças partidárias que estabelecem cotas de delegados para essa ocasião. O aspecto informal está subjacente na entrega de uma única relação de competidores para aprovação pela assembléia, conforme explica Mainwaring (2001:305):

As Convenções geralmente recebem uma chapa única e isso significa que as decisões foram tomadas antes da assembléia. Somente quando as forças concorrentes se mantêm em apertado equilíbrio é que a Convenção decide sobre a composição da chapa do partido. Por isso as Convenções dão a impressão de ser meras formalidades por trás das quais um pequeno grupo de líderes controla o "verdadeiro" mecanismo de seleção de candidatos.

Por esses critérios, preferencialmente frouxos, e pela tradição cultural as mulheres têm sido penalizadas.

As leis eleitorais que incorporavam as cláusulas do Código Civil dificultaram o percurso das brasileiras nos degraus de acesso à representação política, determinando os procedimentos de submissão patriarcal instruídos pela cultura e pelos costumes estabelecidos. Quem se alistava e se candidatava para concorrer a uma eleição, após a vitória do sufragismo em 1932, eram sobretudo as professoras da escola pública. Os litígios regionais da década de 1930 entre o governo das interventorias e as elites remanescentes da Primeira República podem ser contabilizados também na rarefação do número de mulheres entre os candidatos de partidos regionais (Álvares, 1990).

Com a nacionalização dos partidos pela Constituição de 1946 e as regras eleitorais ainda definidas pelas cláusulas estabelecidas de forma seletiva para a entrada das mulheres na cidadania ativa (eleitora) e passiva (candidatura), até 1965 se verifica uma tímida evolução do percentual de mulheres candidatas no período de 1946 a 1982 à Câmara dos Deputados e às Assembléias Legislativas, conforme Tabela 3.

Utilizando as informações subjacentes em dados documentais, é possível concluir que, além dos cenários em que a participação eleitoral teve o predomínio oligárquico de grupos partidários (1945-1962) e das regras eleitorais restritivas à candidatura de mulheres - somente as que exerciam profissões lucrativas -, há também os condicionantes socioculturais definindo o campo da política formal aos homens e ao tipo de jogo político marcado por situações litigantes entre os grupos que aspiravam ao comando local. Por outro lado, nesse mesmo quadro, so- 


\section{Maria Luzia Miranda Álvares}

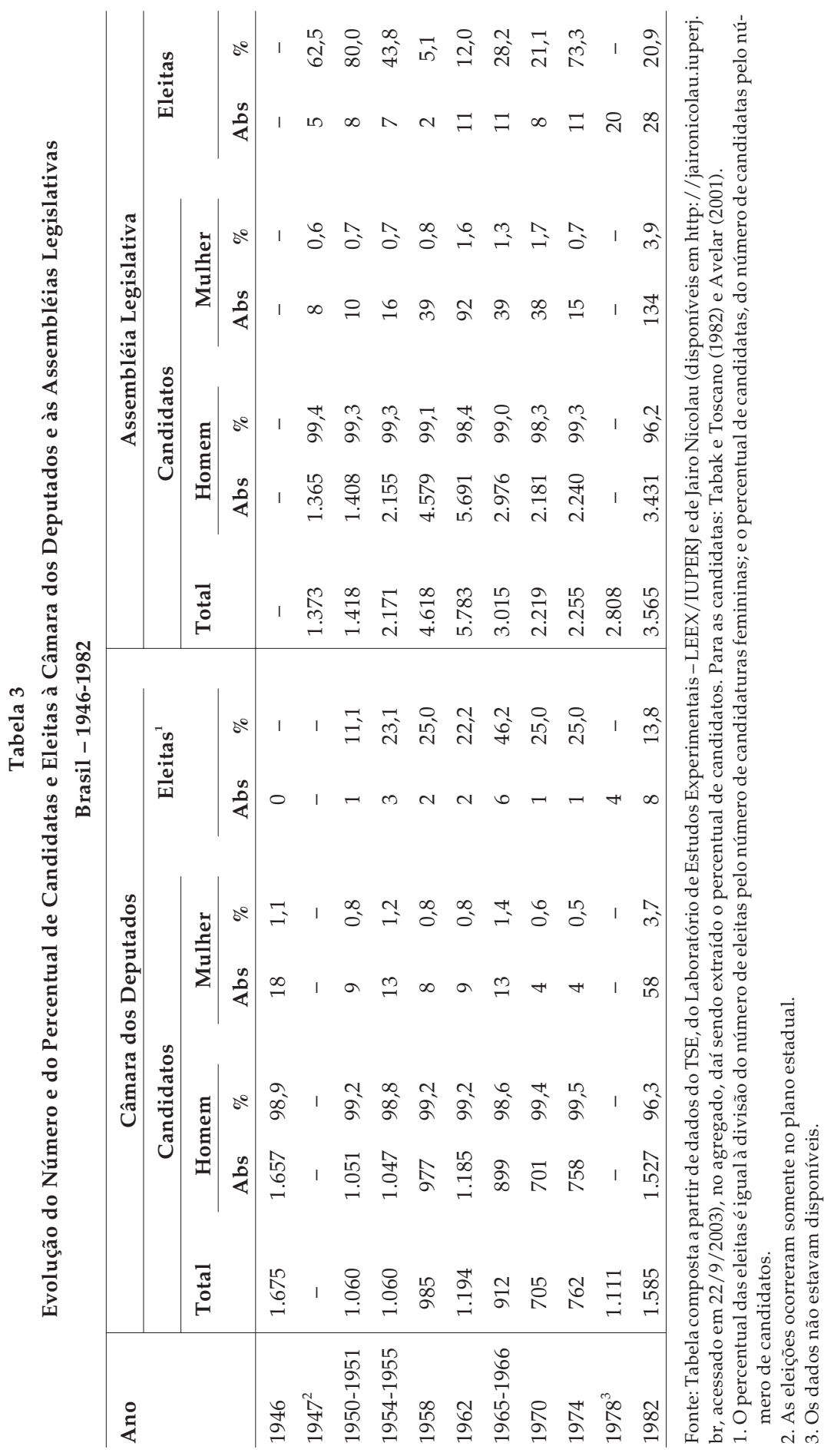


mam-se resquícios do tempo em que as fraturas constitucionais do período militar mantiveram o plebiscito eleitoral e a formação de um sistema bipartidário, embora ferindo os princípios democráticos pela exacerbação da violência política contra os opositores ao regime (1964-1982). Essa situação, que levou à cassação de mandatos dos parlamentares acusados de subversão da ordem política implementada em 1964, favoreceu a candidatura de esposas e irmãs que tiveram seus maridos e parentes nessa condição. Tabak e Toscano (1982:68) registram que, das treze candidatas à Câmara dos Deputados, nas eleições de 1965-1966, das quais saíram seis eleitas,

[...] cinco foram apresentadas pelo MDB e, destas, somente uma tinha eleitorado próprio, pois há quinze anos vinha tendo seu mandato renovado. As quatro deputadas que ingressaram na Câmara Federal, com apoio no eleitorado de seus respectivos cônjuges, tiveram por sua vez os mandatos cassados em $1969^{25}$.

Em 1982, com a distensão política, a criação de novos partidos e a efervescência dos movimentos de mulheres agregadas aos partidos de oposição, houve aumento significativo de candidaturas femininas aos cargos parlamentares, prevalecendo a demanda maior para as Assembléias Legislativas. Quanto às eleitas, o número não foi correspondente, pois, das 58 que competiam à Câmara dos Deputados, somente oito $(13,8 \%)$ se elegeram. Das 134 que concorreram às Assembléias Legislativas, apenas 28 foram exitosas $(20,9 \%)$. Todavia, se comparado aos percentuais do período militar, houve ampliação expressiva do quadro de candidatas e de eleitas.

A Década da Mulher (1975-1985), se de um lado não expressou um padrão de crescimento de candidaturas, conforme se expandiam os grupos feministas e os movimentos de mulheres em nível nacional, de outro serviu de estímulo à demanda maior de mulheres aos cargos parlamentares. Sem esquecer que, nesse período, houve, além da reformulação das leis partidárias, a criação de novos partidos e os eflúvios da redemocratização - ponto decisório nos rumos do país em 1985.

Com uma nova Constituinte após um período autoritário, as mulheres ainda permaneceram entre percentuais baixos nos espaços legislativos, forçando novas regras para o aumento desses números. Em suma: as leis eleitorais no Brasil e a interpretação jurídica apoiaram-se na situação de homens e mulheres descrita no Código Civil e nos costumes, e seguiram duas linhas: a) não ferir institucionalmente os dispositivos 
desse Código; b) não ferir os costumes naturalizados. Como a racionalidade do partido é alcançar representatividade (garantir o maior número de votos e cadeiras), o nível de acesso das mulheres ainda era incipiente nessa organização, porque não dispunha de políticas de inclusão de simpatizantes nem de filiadas enquadradas nos modelos do mercado. Que modelo é esse? O peso da tradição sexista encarecendo o capital político caracteriza os competidores entre aqueles que possuem capital social acumulado na base familiar, no ativismo político ou em profissões que favoreçam reconhecer uma significativa trajetória política aos que aspiram competir. Sem um perfil direcionado para esse mercado a maioria das mulheres deixou de ser "selecionada" e/ ou de oferecer seu nome para candidatura. No entanto, isso não quer dizer que elas estavam "de fora" do ativismo político, pois sua presença sempre se constituiu significativa nos movimentos sociais, nos centros comunitários, nas associações de bairro, ou seja, em outras formas de ação política integradas a uma área mais direta às deliberações públicas enquanto lideranças efetivas. Se a presença nos partidos era insignificante, há registro de mulheres que se dedicavam aos serviços de panfletagem ou à organização de eleitores em tempo eleitoral quando o direito do voto ainda permanecia entre as aspirações das sufragistas $^{26}$.

\section{O Quadro das Eleições Proporcionais de 1986 a 2002 e o Acesso das Mulheres ao Parlamento}

Em um partido, filiados e filiadas podem se sentir motivados / as para a carreira política. Se historicamente o acesso à competição eleitoral se reduzia à demanda masculina, hoje as mulheres estão nos dois lados do mercado eleitoral (demanda e oferta), embora ainda se mantenham absorvidas tanto pela cultura sexista dos papéis tradicionais de gênero quanto por outras transversais que afloram em suas opções pessoais e também na própria atividade política. Uma variável explicativa das condições de maior acesso da mulher à participação política é o processo de modernização social e o índice de urbanização e de desenvolvimento humano, traduzidos pela implementação do desenvolvimento socioeconômico determinante das mudanças culturais e pela ruptura com os valores tradicionais e transformadores da vida das pessoas e da própria esfera pública (Norris e Lovenduski, 1995; Norris e Inglehart, 2000; Inglehart e Norris, 1999; 2003a; 2003b). Essas mudanças trouxeram a erosão da família tradicional, liberalizaram os padrões do comportamento sexual, criaram outra expectativa em torno do casamento 
e do divórcio e ampliaram a aceitação entre os homens e as mulheres dos novos papéis sexuais ao favorecerem os valores pós-modernos de igualdade de gênero no lar, no trabalho, no espaço público. Afirmam Inglehart e Norris (2003a:133):

Onde uma cultura de igualdade de gênero predomina, gera um clima de esperança pelos direitos legais traduzidos de fato em algumas práticas com implementação de reformas institucionais no espaço do trabalho e na esfera pública onde as mulheres vão abraçar oportunidades ampliadas de alfabetização, educação e emprego e em que os papéis tradicionais de homens e mulheres serão transformados dentro de casa e na família (tradução da autora).

Com essas novas oportunidades de incremento educacional, presença na força de trabalho e mudança nos padrões dos papéis tradicionais sexuais, registra-se o progresso das mulheres nos cargos de representação parlamentar. Por outro lado, os partidos têm demonstrado certo interesse em agregar mulheres em seus quadros. A avaliação dos estatutos partidários brasileiros identificou registros de grupos identitários de mulheres, tornando-se uma das fontes de recrutamento de candidatura. Erickson (1993) analisou resultados satisfatórios dos partidos canadenses (Liberal e New Democratic Party - NDP) quando estes apoiaram os núcleos de mulheres com programas e inclusão delas em atividades partidárias desvinculadas das tradicionais.

O quadro de inovações e mudanças foi avaliado por Álvares (2004) por meio da análise dos antecedentes sociais de candidatos e candidatas que se apresentaram nas eleições de 1998 e de 2002 e das convergências e divergências do desenho dessas candidaturas em torno de variáveis como faixa etária, nível de educação, status ocupacional, estado civil, tipo de partido em que as mulheres entraram para a competição eleitoral. Em virtude do espaço destinado a este artigo, não será possível apresentar as tabelas com essas variáveis, mas é possível sumarizar as informações extraídas com os percentuais das candidaturas femininas desde 1986, quando as mudanças da estrutura de oportunidades no Brasil favoreceram um maior avanço das mulheres na competição. $\mathrm{O}$ cálculo da evolução dessas candidaturas possibilita avaliar, em nível comparado em gênero, os pontos percentuais entre os competidores e a procura de cargos nas duas casas legislativas.

Se comparada à Tabela 3, do período de 1946 a 1982, vê-se, na Tabela 4, percentuais de concorrentes bem maiores. Esse avanço projeta o cresci- 


\section{Maria Luzia Miranda Álvares}

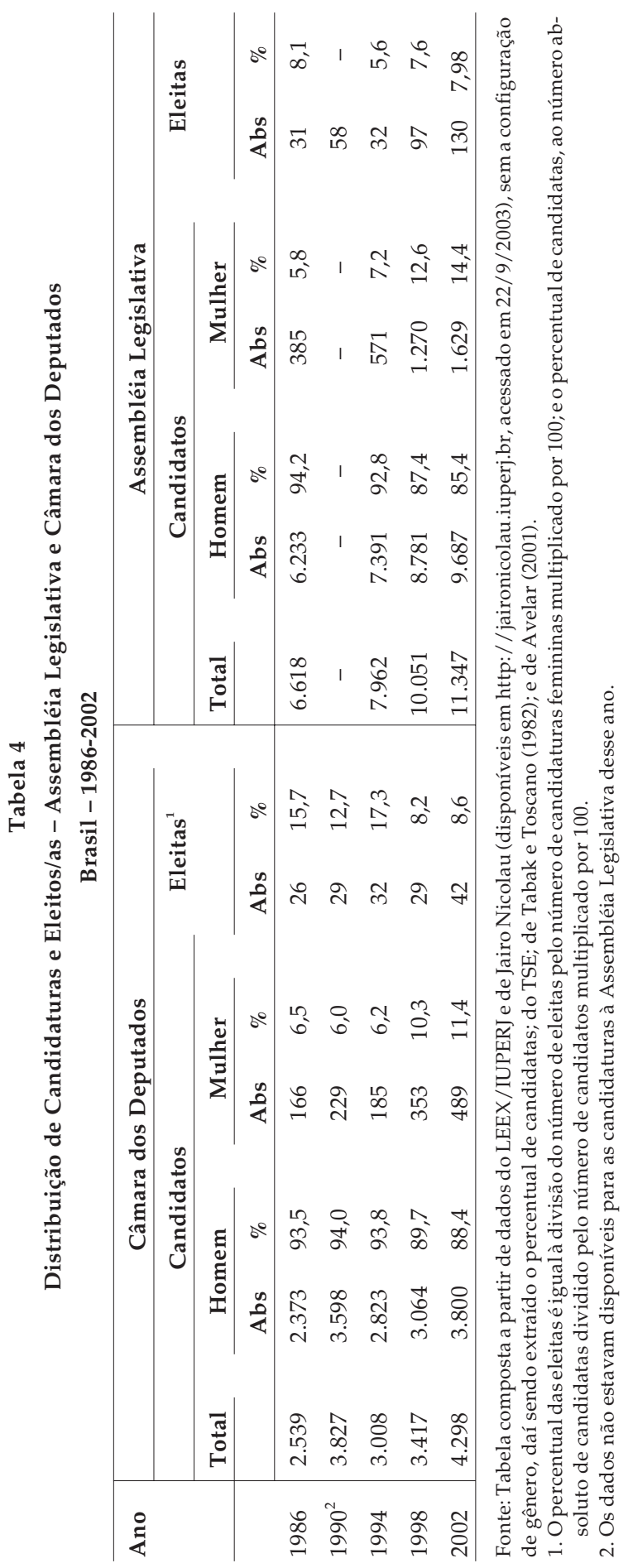


mento dos movimentos de mulheres, a partir do final dos anos 1970, em todo o Brasil ${ }^{27}$. A junção de forças transformou as lideranças dessas entidades - as quais mantinham vínculo com os movimentos nacionais pela anistia e contra a exploração e o conflito no campo, os movimentos nacionais de direitos humanos, os movimentos contra a violência doméstica etc. - na espinha dorsal dos partidos de oposição, como PC do B, PT, PSB e MDB (quando este se opunha ao regime militar). O trabalho de recrutamento político para os movimentos sociais nascentes conferiu respeitabilidade às demandas das mulheres nos bairros urbanos, na zona rural, nos sindicatos e nas fábricas.

Em 1986, a bancada da Câmara dos Deputados detinha a incumbência de elaborar a nova Constituição. Desde 1985 os grupos organizados de mulheres encaminharam propostas de mudança sobre a situação feminina, reivindicando melhores condições de vida e melhores oportunidades para o desempenho de suas atividades, entre outras demandas. Elas participaram dos debates da Constituinte opinando sobre os pontos que queriam modificar, exigindo um novo enfoque sobre seus direitos sociais. Nesse sentido, apresentaram propostas encampadas por um comitê de feministas, que foram incorporadas ao texto da Constituição de 1988.

Sobre a cidadania eleitoral, com a demanda pela igualdade de acesso ao processo decisório, apesar dos debates entre esses grupos, não houve tantos avanços. Silvia Pimentel (1988), coordenadora do comitê assessor dos grupos de mulheres na Constituinte, levantou algumas hipóteses sobre a situação a respeito da baixa presença feminina na competição eleitoral: a) organização incipiente das mulheres e falta de apoio político-eleitoral; b) falta de experiência política (prática específica desse "agir"); c) indiferença do eleitorado à contribuição da mulher no Legislativo; d) dificuldades no entrosamento entre o partido e as mulheres e insensibilidade dos partidos para a superação do problema; e) discriminação contra a mulher candidata; f) falta de recursos financeiros para a campanha ${ }^{28}$. Mesmo assim, representando 5,3\% (1986), 5,8\% (1990) e 6,2\% (1994), as mulheres eleitas à Câmara dos Deputados constituíram discreto crescimento entre os diversos partidos e Estados da Federação; para as Assembléias Legislativas, 3,3\% (1986), $5,5 \%(1990)$ e $3,1 \%(1994)^{29}$.

Quanto às eleições de 1998-2002, os percentuais de candidaturas femininas aos cargos legislativos mostraram evolução crescente. A deman- 
da pela Assembléia Legislativa foi bem maior do que pela Câmara dos Deputados.

É preciso registrar que desde 1995 o Brasil convivia com uma lei de cotas nacional aprovada pelo Legislativo, uma emenda de lei eleitoral apresentada pela então deputada Martha Suplicy, garantindo um percentual de $20 \%$ das vagas de cada partido ou coligação para preenchimento de candidaturas de mulheres nas eleições municipais de 1996. Os debates legislativos, tanto relativos à constitucionalidade da medida quanto para mostrar o peso das barreiras culturais em interpretações sobre a mulher em cargo eletivo, favoreceram uma nova redação da emenda para aprovação e novas propostas para a Comissão de Constituição, Justiça e Redação - CCJR, sendo votada a legislação eleitoral e aprovado, em definitivo, em 1997, o texto final assegurando a adoção de uma cota partidária mínima de $30 \%$ e máxima de $70 \%$ para qualquer um dos sexos. Deve-se esclarecer que esse dispositivo da política de cotas não alcançou o mérito desejado, conforme estudos de Araújo (1999).

Nesses dois períodos, o conjunto de dados de antecedentes sociais dos candidatos e candidatas coletado e analisado por Álvares (2004) favoreceu outras informações. Por exemplo: mostrou que brasileiros e brasileiras se candidatam, para as duas casas legislativas, em idade madura (41 a 50 anos); há predomínio de casados/as, em um percentual equilibrado; a escolaridade é alta, com as mulheres alcançando maior percentual educacional do que os homens; estão distribuídos/as em ocupações cuja freqüência centrou-se, para as mulheres, entre as professoras de 1ㅇ e 2 o graus (atuais ensinos fundamental e médio) e, para os homens, entre comerciantes e advogados, para a Assembléia Legislativa e Câmara dos Deputados.

Um aspecto que chamou a atenção diz respeito a candidaturas de mulheres com a ocupação atribuída de dona-de-casa, levando a reavaliar essa categoria ocupacional com o potencial que está agregando no ativismo político por meio da formação de associações de classe ${ }^{30}$.

Sobre a posição partidária, proporcionalmente, no índice relativo à distribuição de candidaturas e filiados/as, constatou-se que os partidos pequenos $(\mathrm{P}) \mathrm{e}$ "nanicos" $(\mathrm{N})$ do bloco de esquerda têm melhor desempenho na indicação de mulheres para concorrer, aproveitando melhor seu quadro de filiados/as na competição eleitoral, enquanto os partidos grandes $(G)$ têm menores percentuais de indicação de candi- 
daturas femininas, sendo, entretanto, os que elegem mais mulheres, seguidos dos partidos médios (M). A Tabela 5 é uma referência para tal asserção. Quanto aos blocos ideológicos, a distribuição demonstra que a esquerda (67) elege mais mulheres, com $38,9 \%$; o centro (60), com $34,8 \%$; e a direita (45), $\operatorname{com} 26,2 \%$.

Tabela 5

Distribuição das Eleitas em Partido e Cargo

Brasil - 2002

\begin{tabular}{l|cc|c}
\hline Partido & \multicolumn{2}{|c|}{ Cargo } & Total \\
& Assembléia Legislativa & Câmara dos Deputados & \\
\hline PT & 29 & 15 & 44 \\
PSDB & 22 & 5 & 27 \\
PMDB & 21 & 6 & 27 \\
PFL & 9 & 6 & 15 \\
PSB & 9 & 2 & 11 \\
PTB & 4 & 3 & 7 \\
PC do B & 3 & 4 & 7 \\
PP & 7 & - & 7 \\
PDT & 6 & - & 6 \\
PL & 5 & - & 5 \\
PPS & 4 & 1 & 5 \\
PSC & 3 & - & 3 \\
PSD & 2 & - & 2 \\
PST & 2 & - & 2 \\
PT do B & 1 & - & 1 \\
PTN & 1 & - & 1 \\
PAN & 1 & - & 1 \\
Prona & 1 & - & 1 \\
\hline Total & $\mathbf{1 3 0}$ & $\mathbf{4 2}$ & 172 \\
\hline
\end{tabular}

Fonte: Centro Feminista de Estudos e Assessoria - Cfemea (http://www.cfemea.org.br).

\section{O PROCESSO DE SELEÇÃO DE CANDIDATURAS E A CARREIRA LEGISLATIVA DAS MULHERES}

O estudo sobre seleção de candidaturas objetivou avaliar um dos degraus de acesso da mulher à carreira política considerando os arranjos partidários formais e informais que submetem os/as cidadãos/ãs aptos/as a entrar na competição eleitoral. A trajetória das mulheres que aspiram a um cargo parlamentar segue a formação de praxe, sendo construída desde o engajamento partidário em dois graus: simpatizante e membro filiado. Esses níveis exercem barreiras ao avanço das mulheres nesse âmbito da política eleitoral em virtude da cultura domi- 
nante no imaginário social responsável pela definição de um modelo de aspirante ao cargo legislativo, desconectado das condições históricas a que as mulheres foram submetidas nas relações sociais, com a predominância hierarquizada do homem, branco e com experiência nesse nível de participação política. Isso concorreu para a baixa motivação e presença delas nos partidos, com informação deficiente para se tornarem simpatizantes; pelo não-pertencimento partidário, não se filiam.

Os desenhos do recrutamento de candidaturas demonstraram que a escolha de candidatos/as: é um importante estágio da disputa eleitoral; apresenta fatores institucionais (elegibilidade), partidários (filiação) e pessoais (motivação); ocorre dentro dos partidos, evidenciando a natureza de centralização/descentralização interna dessa organização; e, por sua natureza, difere entre a indicação e a eleição de filiados / as para a composição das listas de candidatos/as. Trata-se de um pré-escrutínio de nomes avaliados pelas lideranças (demanda) e pelo/a próprio/a aspirante (oferta), conforme apresentem antecedentes sociais que se adaptem ao reconhecimento de um perfil de competidor/a com uma carreira política valorizada pelo mercado político. Nessa interação entre oferta e demanda de nomes, verificam-se os obstáculos à entrada das mulheres na competição tanto pela parcimônia dos recursos pessoais desse gênero, enfraquecendo a motivação para concorrer (experiência política), quanto pela avaliação do partido àqueles / as com mais qualificação e que expressem prospecção de força eleitoral. Aqui o campo social fornece os subsídios para pensar que, enquanto os homens constroem sua trajetória valorizada, socialmente, na profissão, na política, sendo o papel esperado deles, as mulheres originariamente se reproduziram sob forte desqualificação de tarefas, julgando-se com dificuldades de realização pessoal, embora consigam ultrapassar essa emblemática configuração social.

Quanto ao modelo do selecionador, distribui-se entre os membros partidários (Executiva, Diretórios etc.), entre as agências de representação partidária (convenções) e, sobretudo, entre as lideranças do partido. Define-se entre a maior inclusão (quando os selecionadores estão em uma base ampliada) ou a maior exclusão (redução da dimensão do selecionador para um único líder), medindo com isso a democracia partidária. Nesse estágio de definição de candidaturas, as mulheres e as minorias têm sido tratadas de forma diferenciada, como prova o sistema de cotas a que se submetem para equilibrar a seleção, sendo esse o 
processo de descentralização incorporada evidenciado no modelo de Hazan (2002).

A montagem das listas partidárias e o perfil dos/as selecionados/as constatam a predominância de homens na disputa, com as mulheres apresentando crescimento percentual significativo ao dos parceiros na procura de cargos parlamentares, conforme as tabelas apresentadas.

Mais de $80 \%$ de homens são indicados pelos partidos e estão interessados na competição, com a presença das mulheres sendo ainda residual - um nível de desequilíbrio que se pode originar das dimensões do sistema cultural secular sexista e do habitus às regras institucionais que, por muito tempo, obstaculizaram a progressiva presença desse gênero na política eleitoral e, conseqüentemente, a entrada no partido político e a escolha pelo eleitorado (outra forma de seleção). É possível que esse sistema cultural tenha deslocado a ambição delas para outros tipos de ativismo, como a organização de associações as mais diversas, entre as quais hoje é notória a de donas-de-casa, em que elas exercem uma liderança específica com avanços atuais na demanda por um cargo eletivo.

O âmbito da trajetória política está construído em uma seqüência temporal e estrutural de fatores integrantes do capital social. Pode-se constituir também uma síntese inicial em um vetor específico da política: o partido e a competição eleitoral. No aspecto mais amplo dessa trajetória, o acúmulo de representatividade profissional e o ativismo político atraem um potencial de informações que favorece a exposição pessoal e a dimensão da atividade exercida, estágios que evidenciam a popularidade pública do/a filiado/a, convergindo para o incentivo partidário à competição e conseqüente seleção de seu nome à lista partidária. No caso de essa trajetória iniciar no estágio da atuação partidária, a filiação deve ser a primeira fase de sedução pelo partido, e nessa integração se encontram as diversas atividades geradas e acumuladas até o momento de maturidade para o exercício de um mandato em cargo executivo e/ou parlamentar, culminância dessa trajetória, além de revivência para outros vôos da carreira política.

As experiências advindas dessa trajetória político-eleitoral são as que mais enredam os homens e se tornam obstáculos à presença da mulher: a baixa integração desse gênero ao partido, sua ausência no ativismo partidário e nos cargos estatutários mais evidentes, e a baixa competição aos cargos eletivos. Tornam-se fatores dessa emblemática relação 
mulher e política eleitoral: o tempo de exclusão da cidadania política; o acúmulo de papéis domésticos, que acarretam falta de tempo para as práticas políticas, ou brokerage occupations (Offerlé, 1999) a marca do preconceito (direto e indireto) ao "que fazer" feminino; a visão equivocada sobre a ascensão feminina ao cargo político.

A motivação para a competição eleitoral e a convivência com as "coisas da política" ainda se tornam um forte empecilho para os resultados mais equilibrados na competição eleitoral entre os gêneros. Quanto à demanda do partido pelas candidaturas femininas, está em uma fase em que essa organização se encontra impactada pela presença das mulheres explodindo em todos os ambientes nos quais se integram. Os valores negativos que a política carreou para afastá-las de suas hostes ("a política é suja", "há corrupção na política", entre outros) hoje têm sido apresentados para tentar seduzir esse gênero à criação de recursos de "saneamento básico" para uma das áreas de maior importância na vida de uma nação. É uma fase em que o "casamento" se depara com probabilidades asseguradas de sobreviver somente se houver certeza de atração de votos. O partido é movido racionalmente por esse recurso de domínio da democracia eleitoral; e a relação direta entre ele e o/a potencial filiado/a se encontra nesta equação: o/a filiado/a está para o voto assim como o voto está para o aumento do poder político do partido.

(Recebido para publicação em agosto de 2007)

(Versão definitiva em novembro de 2008) 


\section{NOTAS}

1. Para Duverger (1970), a aferição do número de adeptos tem dois tipos de estudo: evolução dos partidos e sua composição. Um terceiro a ser considerado é o recrutamento dos simpatizantes do partido. Essa abordagem duvergeriana sobre o grau de influência dos partidos na designação dos candidatos para a composição da lista nominal e sobre os fatores presentes nessas indicações, como o peso das lideranças na eleição e na indicação (na forma de cooptação), subsidiou os novos e atuais trabalhos de outros estudiosos da área.

2. Em seus estudos, Norris (1993) e Norris e Lovenduski (1995) usam o termo para analisar tanto o recrutamento político quanto o legislativo como uma das funções básicas de todo o sistema político, investigando fatores específicos, como: quem se torna candidato, como e por que isso ocorre.

3. Certas ocupações de cargo público ou das Forças Armadas, Judiciário e polícia e executivos de corporação pública, conduta pessoal, razões de insanidade, critérios de escolaridade, não quitação de débitos, entre outros.

4. Contudo, há os que são controlados em detalhes por leis nacionais, como Estados Unidos, Alemanha, Noruega, Finlândia, Turquia e Argentina. Nesses casos, a seleção de candidaturas se distribui em eleições primárias abertas (Estados Unidos), em que qualquer cidadão eleitor do país entra na escolha votando nos candidatos de sua preferência; e em eleições primárias fechadas, permitidas somente aos filiados partidários para escolherem seus candidatos.

5. Hoje, nas democracias liberais, poucos partidos se utilizam desse método para selecionar candidatos.

6. Sobre as questões levantadas em torno do gatekeeper e do recrutamento de candidaturas de mulheres, ver também Norris (1997).

7. Como a apresentação de folha corrida da polícia, a declaração de bens, a inscrição do prenome ou do nome abreviado ("desde que a supressão não estabeleça dúvida quanto à sua identidade", segundo o Código Eleitoral de 1965) etc.

8. Cf. o texto da Lei n⿳9 9.096/95, com minúcias na definição de quem se filia, prazos entre a filiação e a candidatura e outros itens exigidos ao candidato.

9. Foram analisados os 27 estatutos partidários oficialmente registrados no Tribunal Superior Eleitoral - TSE, em 2002. Dessa análise, foi elaborado um quadro com o arcabouço estatutário da formação da base de seleção e do perfil do filiado.

10. Mair e Biezen (2001) registram, em seus estudos entre grandes e pequenas democracias, assim como entre novas e velhas, o declínio do quadro de filiados partidários desses sistemas políticos.

11. Convencionalmente foram os partidos determinados em blocos ideológicos de direita, centro e esquerda, que necessariamente não podem ser congelados em um mesmo padrão entre os diversos sistemas partidários. Utilizo a categorização de Veiga (1999) e a minha perspectiva própria das eleições analisadas: bloco de direita: PPB / PP; PFL, PL, PTB, PSD, PMN, PMB, Prona, PRN, PSC, PT do B, PTC, PRP, PSL, PHS, PSDC, PTN, PRTB, PAN; centro: PMB, PSDB, PDT; e esquerda: PT, PSB, PC do B, PCB, PPS, PV, PSTU, PCO. 
12. O tamanho do partido foi estudado por Rae (1967) através do percentual dos votos obtidos nas eleições e / ou do percentual de assentos partidários no Parlamento. Para essa classificação, foi extraída a média do índice de força eleitoral - IFE dos partidos paraenses que competiram em 2002 (Assembléia Legislativa e Câmara dos Deputados), daí saindo a classificação utilizada, constando: grandes: PMDB, PL, PDT, PP, PSDB, PT e PTB; médios: PSD e PSB; pequenos: PST, PC do B, PPS e PFL; micros ou "nanicos": PV, PSL, PT do B, PSTU, PRP, PTC, PCB, PGT, Prona, PAN, PMN, PRTB, PSDC, PSC, PHS e PTN.

13. Os partidos novos não foram classificados aqui.

14. A variação foi extraída do percentual de mulheres filiadas sobre o percentual masculino de cada partido.

15. O PMDB e o PP trazem as raízes do multipartidarismo criado após o golpe de 1964, advindo das siglas MDB e Arena, respectivamente, depois PMDB e PDS, com esse último sendo retificado nas siglas PPR e PPB. Incluem-se entre os partidos dos blocos ideológicos do centro e da direita. O PT, caracterizado de esquerda, é histórico não só por ser da fase do multipartidarismo pós-1964, como também por sair do interior da classe operária e ter mobilizado, em pouco tempo, um contingente significativo de simpatizantes e filiados/as.

16. Os autores anglo-americanos enfocados anteriormente tratam da situação dos partidos europeus, mas o que chamou a atenção para sua utilização foi a referência de seus estudos ao sistema eleitoral aos quais esses partidos se inscrevem, tanto em um sistema majoritário quanto em um de representação proporcional de lista. Considerando que o sistema eleitoral brasileiro se enquadra nas características desse último e que o modelo de Hazan (2002) trata de seleção de candidaturas na base partidária nesses sistemas, a aplicação do modelo procurou ater-se a um objeto verificável - o estatuto partidário - que evidencia o sistema formal de elaboração das listas pelos partidos brasileiros.

17. Hazan (2002) confere apenas dois: indicação e votação.

18. Este Núcleo de Base agrupa nove filiados, mas é aberto a não filiados de âmbito municipal ou setorial.

19. Estatuto aprovado na Convenção de 24/3/1996 (3ํㅡㄹ. ed.), Brasília, junho de 1999, pp. 29-32.

20. Esse Conselho (arts. 71 e 72) é formado pelos membros da Comissão Executiva Nacional; pelos presidentes dos Diretórios Estaduais; e sendo filiados ao partido: os ex-presidentes nacionais, ex-presidentes da República, governadores do Estado, presidentes da Câmara dos Deputados e Senado; ex-presidentes da Câmara dos Deputados e Senado; e ex-líderes do partido nas duas casas.

21. Ex-PPB. Estatuto aprovado nas Convenções Nacionais de 3/4/2001. Diretório Nacional do PPB. Senado Federal.

22. Os movimentos disponibilizados aos Diretórios das três áreas organizadas são considerados os de: Juventude Progressista; Ação da Mulher Progressista; do Trabalhador Progressista.

23. Para as coligações, independentemente do número de partidos integrados, os registros de candidatos serão até o dobro do número de lugares a preencher (Lei $\mathrm{n} \underline{\mathrm{o}}$ 9.504/97, art. 10, § 1ํํ). Cf. Instrução no $53 / 2002$. 
24. Essa questão foi avaliada por Álvares (2004) em uma fórmula que dimensionou o índice potencial de candidaturas e filiação - IPCF, demonstrando-se em percentuais o desempenho dos partidos na indicação entre homens e mulheres.

25. Situação semelhante também ocorreu em Taiwan, conforme relato de Bey-Ling Sha (2003), no qual a autora revela que, historicamente, entre os partidos taiwandeses, as esposas de maridos presos políticos assumem uma candidatura para ocupar o lugar deles. São atitudes que se instalam no período outside the party, ou dang-wai, quando o DPP foi perdendo a coalizão organizada de políticos oposicionistas e foi se instalando esse fenômeno de as esposas tomarem o lugar dos maridos, sendo indicadas tanto pelo DPP quanto pelo Kuomintang Party - KMT, mas não são vistas nas mesmas situações, pois os primeiros foram aprisionados por questões políticas e os do KMT são presos por pertencerem a gangland connections. Essa diferença distingue os papéis que as mulheres assumem ao tomarem o lugar dos maridos. As do DPP dizem que assumiram porque são ativistas e acompanham os mesmos ideais democráticos dos maridos presos. Interessante pesquisar, nos estados brasileiros, a quantidade de esposas que assumiram o papel político do marido, a partir das eleições pós-1964, e que se transformaram em lideranças, com eleitorado próprio.

26. Em estudo anterior, Álvares (1990) identifica a adesão das mulheres paraenses às facções partidárias por meio das ligas femininas que, no Pará, desde 1912 se envolviam em litígios políticos oligárquicos. Em outro trabalho (Álvares, 1999), avalia a presença das mulheres nos estatutos do PSD, mobilizadas no alistamento eleitoral.

27. Cf. Hellmann, 1995; Pinto, 1992. Segundo Alvarez (2000), esses grupos de mulheres se articularam durante as décadas de 1960-1970, sendo a maioria fundadora da segunda onda do feminismo latino-americano. Reagindo às políticas estatais neoliberais opressivas, engajando-se em organizações clandestinas de esquerda e nos partidos legais de oposição, concentradas no ativismo das mulheres operárias e pobres, dos grupos de mulheres comunitárias, lutas de sobrevivência, sindicatos e movimentos pelos direitos humanos, trabalhando junto às mulheres dos setores populares, esses grupos ficaram conhecidos como "movimento de mulheres". Há detalhes mais aprofundados do descentramento do movimento feminista latino-americano. Salvo uma referência a Organizações Não-Governamentais - ONGs feministas articuladas em rede e incluindo nesta os partidos políticos, não há nenhuma referência ao formato desses grupos que chamo de "grupo de feministas de núcleo partidário". Delgado e Soares (1995), entretanto, referem-se a eles.

28. Pimentel $(1985 ; 1988)$ tem dois trabalhos importantes que tratam dessas questões e analisam os textos constitucionais brasileiros em nível comparado.

29. Os percentuais encontrados são resultados da extração do número de eleitas pela bancada.

30. As donas-de-casa passaram a fazer parte do cenário político nacional organizando-se em associações estaduais, além de criarem uma confederação compondo parcerias diversificadas tanto entre instituições públicas quanto privadas, com demandas específicas de cidadãs, lutando pelos direitos de proteção e defesa do consumidor, e pelo reconhecimento da identidade de trabalhadoras e da garantia previdenciária. Desde 1988 elas têm direito à aposentadoria, mas esse benefício tem sido pouco utilizado. Com a nova lei da Previdência Social, entrou no debate um projeto de emenda constitucional de autoria da deputada federal Luci Choinacki (PT/SC) cuja matéria procurou assegurar às donas-de-casa, a partir dos 60 anos, uma pensão no 


\section{Maria Luzia Miranda Álvares}

valor de dois salários mínimos, desde que não disponham de qualquer fonte de renda, ou benefício de assistência, ou previdenciário. Recentemente, o Senado Federal aprovou a Proposta de Emenda à Constituição - PEC (n- 358/05), que garante essa aposentadoria, em regime especial, das donas-de-casa sem renda própria ou de baixa renda, com o benefício de um salário mínimo.

\section{REFERÊNCIAS BIBLIOGRÁFICAS}

ÁLVARES, Maria L. Miranda. (1990), Saias, Laços e Ligas: Construindo Imagens e Lutas. Um Estudo sobre a Participação Política e Partidária das Mulheres Paraenses 1912-1937. Dissertação de mestrado, NAEA/UFPA, Belém.

(1999), “Experiências e Regulamento: As Legionárias Paraenses nas Eleições de 1946 e 1950, in M. L. M. Álvares e E. F. dos Santos (orgs.), Olhares e Diversidades: Os Estudos sobre Gênero no Norte e Nordeste. Belém, Gepem/CFCH/UFPA/Redor-N/NE.

. (2004), Mulheres na Competição Eleitoral: Seleção de Candidaturas e o Padrão de Carreira Política no Brasil. Tese de doutorado, IUPERJ, Rio de Janeiro.

ALVAREZ, Sonia. (2000), “A 'Globalização' dos Feminismos Latino-Americanos: Tendências dos Anos 90 e Desafios para o Novo Milênio", in S. Alvarez, E. Dagnino e A. Escobar (orgs.), Cultura e Política nos Movimentos Sociais Latino-Americanos. Belo Horizonte, Editora UFMG.

ARAÚJO, Clara. (1999), Cidadania Incompleta: O Impacto da Lei de Cotas sobre a Representação Política das Mulheres no Brasil. Tese de doutorado, UFRJ/PPGSA, Rio de Janeiro.

AVELAR, Lúcia. (2001), Mulheres na Elite Política Brasileira. São Paulo, Fundação Konrad Adenauer/Editora UNESP.

BORBA, Ângela, FARIA, Nalu e GODINHO, Tatau. (1998), Mulher e Política: Gênero e Feminismo no Partido dos Trabalhadores. São Paulo, Fundação Perseu Abramo.

CZUDNOWSKI, Moshe M. (1975), "Political Recruitment", in F. I. Greenstein e N. W. Polsby (eds.), Micropolitical Theory. Handbook of Political Science. Reading Massachusetts, Addison-Wesley Publishing Company, vol. 2.

DELGADO, Maria Berenice e SOARES, Vera Lucia Lemos. (1995), “O Movimento de Mulheres na Transição Democrática Brasileira", in M. Hellmann (org.), Movimentos Sociais e Democracia no Brasil. São Paulo, Marco Zero.

DUVERGER, Maurice. (1970), Os Partidos Políticos. Rio de Janeiro, Zahar.

ERICKSON, Lynda. (1993), “Making Her Way in: Women, Parties and Candidacies in Canada", in J. Lovenduski e P. Norris (eds.), Gender and Party Politics. London, Sage. 
GALLAGHER, Michael e MARSH, Michael. (1988), Candidate Selection in Comparative Perspective: The Secret Garden of Politics. London/Newbury Park, Sage.

HAZAN, Reuven. (2002), "Candidate Selection", in L. LeDuc, R. G. Niemi e P. Norris (eds.), Comparing Democracies 2. New Challenges in the Study of Elections and Voting. London/New Delhi, Sage/Thousand Oaks.

HELLMANN, Michaela (org.). (1995), Movimentos Sociais e Democracia no Brasil. São Paulo, Marco Zero.

HTUN, Mala N. (2002), "Mujeres y Poder Político en Latinoamérica", in M. Méndez Montalvo e J. Ballington (orgs.), Mujeres en el Parlamento. Más allá de los Números. Strömsborg, International IDEA. Disponível em http: / / www. idea.int, acessado em 9/6/2003.

INGLEHART, Ronald e NORRIS, Pippa. (1999), “The Developmental Theory of the Gender Gap: Women and Men's Voting Behavior in Global Perspective". Disponível em http:/ / www.pippanorris.com, acessado em 3/1/2002.

. (2003a), "Introduction: Explaining the Rising Tide of Gender Equality", in Rising Tide: Gender Equality and Cultural Change around the World. Cambridge, Cambridge University Press. Disponível em http:/ / www.pippanorris.com, acessado em 2003.

. (2003b), “Women as Political Leaders", in Rising Tide: Gender Equality and Cultural Change around the World. Cambridge, Cambridge University Press. Disponível em http:/ / www.pippanorris.com, acessado em 2003.

LIMA JUNIOR, Olavo Brasil de. (1983), Os Partidos Políticos Brasileiros: A Experiência Federal e Regional: 1945 a 1964. Rio de Janeiro, Graal.

(org.). (1991), Sistema Eleitoral Brasileiro: Teoria e Prática. Rio de Janeiro, IUPERJ.

LOVENDUSKI, Joni e NORRIS, Pippa. (1993), Gender and Party Politics. London, Sage.

MAINWARING, Scott. (2001), Sistemas Partidários em Novas Democracias: O Caso do Brasil. Porto Alegre/Rio de Janeiro, Mercado Aberto/Editora FGV.

MAIR, Peter e BIEZEN, Ingrid van. (2001), "Party Membership in Twenty European Democracies, 1980-2000". Party Politics, vol. 7, no 1, pp. 5-21.

MATLAND, Richard E. (2002), “Estrategias para Ampliar la Participación Femenina en el Parlamento. El Proceso de Selección de Candidatos Legislativos y los Sistemas Electorales", in M. Méndez-Montalvo e J. Ballington (orgs.), Mujeres en el Parlamento. Más allá de los Números. Strömsborg, International IDEA. Disponível em http:// www.idea.int, acessado em 9/6/2003.

NORRIS, Pippa. (1993), "Comparing Legislative Recruitment", in J. Lovenduski e P. Norris, Gender and Party Politics. London, Sage.

. (1996), “Legislative Recruitment”, in L. LeDuc, R. G. Niemi e P. Norris (eds.), Comparing Democracies. Elections and Voting in Global Perspective. London, Sage.

. (1997), Passages to Power. Legislative Recruitment in Advanced Democracies. Cambridge, Cambridge University Press.

e LOVENDUSKI, Joni. (1995), Political Recruitment: Gender, Race and Class in the British Parliament. Cambridge, Cambridge University Press. 
NORRIS, Pippa e INGLEHART, Ronald. (2000), Cultural Barriers to Women's Leadership: A Worldwide Comparison. Trabalho apresentado no International Political Science Association World Congress, Quebec. Disponível em http://ksghome. harvard.edu/ p pnorris, acessado em 29/11/2001.

OFFERLÉ, Michel. (1999), La Profession Politique XIX-XX Siècles. Paris, Editions Belin.

PENNINGS, Paul e HAZAN, Reuven. (2001), “Democratizing Candidate Selection: Causes and Consequences". Party Politics, vol. 7, no 3, pp. 267-275.

PIMENTEL, Silvia. (1985), A Mulher e a Constituinte: Uma Contribuição ao Debate. São Paulo, Cortez.

. (1988), "A Mulher Brasileira, a Constituinte e a Participação Política", in N. V. de Carvalho (org.), A Condição Feminina. São Paulo, Vértice/Revista dos Tribunais.

PINTO, Celi. (1992), “Movimentos Sociais: Espaços Privilegiados da Mulher Enquanto Sujeito Político", in A. O. Costa e C. Bruschini (orgs.), Uma Questão de Gênero. São Paulo, Rosa dos Tempos.

PORTO, Walter Costa. (2002), O Voto no Brasil: Da Colônia à 6a República (2a ed.). Rio de Janeiro, Topbooks.

RAE, Douglas W. (1967), The Political Consequences of Electoral Laws. New Haven, Yale University Press.

RAHAT, Gideon e HAZAN, Reuven. (2001), “Candidate Selection Methods: An Analytical Framework". Party Politics, vol. 7, no 3, pp. 297-322.

SANTOS, Wanderley G. dos. (1994), Regresso. Máscaras Institucionais do Liberalismo Oligárquico. Rio de Janeiro, Opera Nostra.

SHA, Bey-Ling. (2003), "Gender and Party Politics: Case Study of the Democratic Progressive Party on Taiwan", in G. D. Rawnsley e M.-Y. T. Rawnsley (eds.), Political Communications in Greater China: The Construction and Reflection of Identity. London, RoutledgeCurzon, pp. 213-254.

TABAK, Fanny e TOSCANO, Moema. (1982), Mulher e Política. Rio de Janeiro, Paz e Terra.

VEIGA, Edir. (1999), Formato e Evolução do Sistema Partidário do Pará - Uma Análise Comparada: 1945-62 e 1986-98. Dissertação de mestrado, IUPERJ, Rio de Janeiro. 


\section{FONTES CONSULTADAS}

Constituição da República dos Estados Unidos do Brasil (de 16 de julho de 1934).

Constituição da República dos Estados Unidos do Brasil (de 5 de outubro de 1988).

Código Eleitoral de 1932 - Decreto no21.076, de 24 de fevereiro de 1932.

Código Eleitoral de 1965 - Lei no 4.737, de 15 de julho de 1965. 


\section{LISTA DE SIGLAS}

Arena - Aliança Renovadora Nacional

MDB - Movimento Democrático Brasileiro

PAN - Partido dos Aposentados da Nação

PC do B - Partido Comunista do Brasil

PCB - Partido Comunista Brasileiro

PCO - Partido da Causa Operária

PDT - Partido Democrático Trabalhista

PFL - Partido da Frente Liberal

PGT - Partido Geral dos Trabalhadores

PHS - Partido Humanista da Solidariedade

PL - Partido Liberal

PMB - Partido Municipalista Brasileiro

PMDB - Partido do Movimento Democrático Brasileiro

PMN - Partido da Mobilização Nacional

PP - Partido Progressista

PPB / PP - Partido Progressista Brasileiro

PPS - Partido Popular Socialista

PRN - Partido da Reconstrução Nacional

Prona - Partido de Reedificação da Ordem Nacional

PRP - Partido Reformador Trabalhista

PRTB - Partido Renovador Trabalhista Brasileiro

PSB - Partido Socialista Brasileiro

PSC - Partido Social Cristão

PSD - Partido Social Democrático

PSDB - Partido da Social Democracia Brasileira

PSDC - Partido Social Democrata Cristão

PSL - Partido Social Liberal

PST - Partido Social Trabalhista

PSTU - Partido Socialista dos Trabalhadores Unificados

PT - Partido dos Trabalhadores

PT do B - Partido Trabalhista do Brasil

PTB - Partido Trabalhista Brasileiro

PTC - Partido Trabalhista Cristão

PTN - Partido Trancredista Nacional

PV - Partido Verde 


\section{ABSTRACT}

Brazilian Women in Electoral Contests: Candidate Selection and Degree of Access to Congressional Office

Candidate selection is a key element in the link between electoral systems and political parties. Selection is necessary for candidates to access elective political office, where Brazilian women are still underrepresented. This article examines Brazilian women's presence in electoral contests, constructing a model to explain the preliminary candidate selection process, one of the parties' main roles. The article then outlines the steps for accessing office, from voter to party member to candidate, focusing on candidacies in the 1998 and 2002 Brazilian elections and the evolution in women's candidacies since 1946.

Key words: political parties; party affiliation; women's representation; access to political office

\section{RÉSUMÉ}

Femmes Brésiliennes en Temps de Dispute Électorale: Sélection des Candidatures et Accessibilitè aux Postes Parlementaires

La sélection des candidatures est l'une les principales fonctions d'articulation entre le système électoral et les partis politiques. Cette fonction est indispensable pour l'accès des candidats aux postes de représentation politique, où les femmes sont encore sous-représentées. Dans cet article, on examine la présence des femmes dans la dispute électorale, à travers la construction d'un modèle de pré-sélection des candidatures - l'une des fonctions de chaque parti - et l'on souligne l'accessibilité des électeurs à la catégorie d'affiliés aux partis et des candidatures pour les élections brésiliennes de 1998 et de 2002, montrant l'évolution des candidatures féminines depuis 1946.

Mots-clé: partis politiques; affiliation aux partis; représentation féminine; accès au pouvoir politique 